Effects of Urbanization on the Chemical, Physical, and Biological Characteristics of Small Blackland Prairie Streams in and Near the Dallas-Fort Worth Metropolitan Area, Texas

Chapter $\mathrm{C}$ of

Effects of Urbanization on Stream Ecosystems in Six Metropolitan Areas of the United States

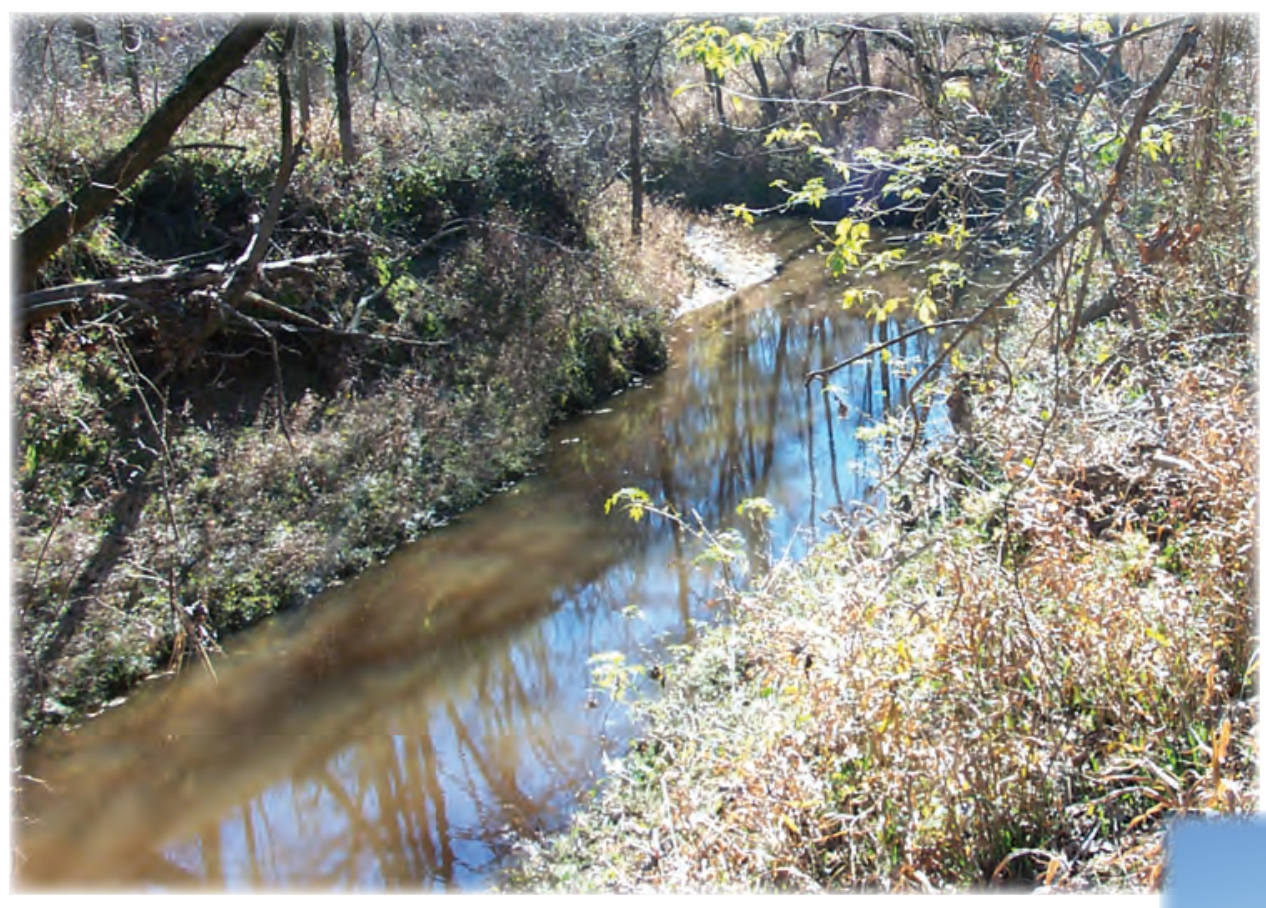

Scientific Investigations Report 2006-5101-C 


\section{Front cover:}

Left Johnson Creek at Arlington, Texas, near Interstate Highway 20 bridge.

Right Little Pin Oak Creek at Richland, Texas, near Interstate Highway 45.

Back cover: Johnson Creek at Arlington, Texas, near Interstate Highway 20 bridge. 


\section{Effects of Urbanization on the Chemical, Physical, and Biological Characteristics of Small Blackland Prairie Streams in and Near the Dallas-Fort Worth Metropolitan Area, Texas}

Chapter $\mathrm{C}$ of

Effects of Urbanization on Stream Ecosystems in Six Metropolitan Areas of the United States

By J. Bruce Moring

U.S. Geological Survey National Water Quality Assessment Program

Scientific Investigations Report 2006-5101-C 


\section{U.S. Department of the Interior \\ KEN SALAZAR, Secretary}

\section{U.S. Geological Survey \\ Suzette M. Kimball, Acting Director}

U.S. Geological Survey, Reston, Virginia: 2009

This and other USGS information products are available at http://store.usgs.gov/
This and other USGS information products are available at http://store.usgs.gov/
U.S. Geological Survey
Box 25286, Denver Federal Center
Denver, CO 80225
To learn about the USGS and its information products visit http://www.usgs.gov/
1-888-ASK-USGS

Any use of trade, product, or firm names is for descriptive purposes only and does not imply endorsement by the U.S. Government.

Although this report is in the public domain, permission must be secured from the individual copyright owners to reproduce any copyrighted materials contained within this report.

Suggested citation:

Moring, J.B., 2009, Effects of urbanization on the chemical, physical, and biological characteristics of small Blackland Prairie streams in and near the Dallas-Fort Worth metropolitan area, Texas: U.S. Geological Survey Scientific Investigations Report 2006-5101-C, $31 \mathrm{p}$. 


\section{Contents}

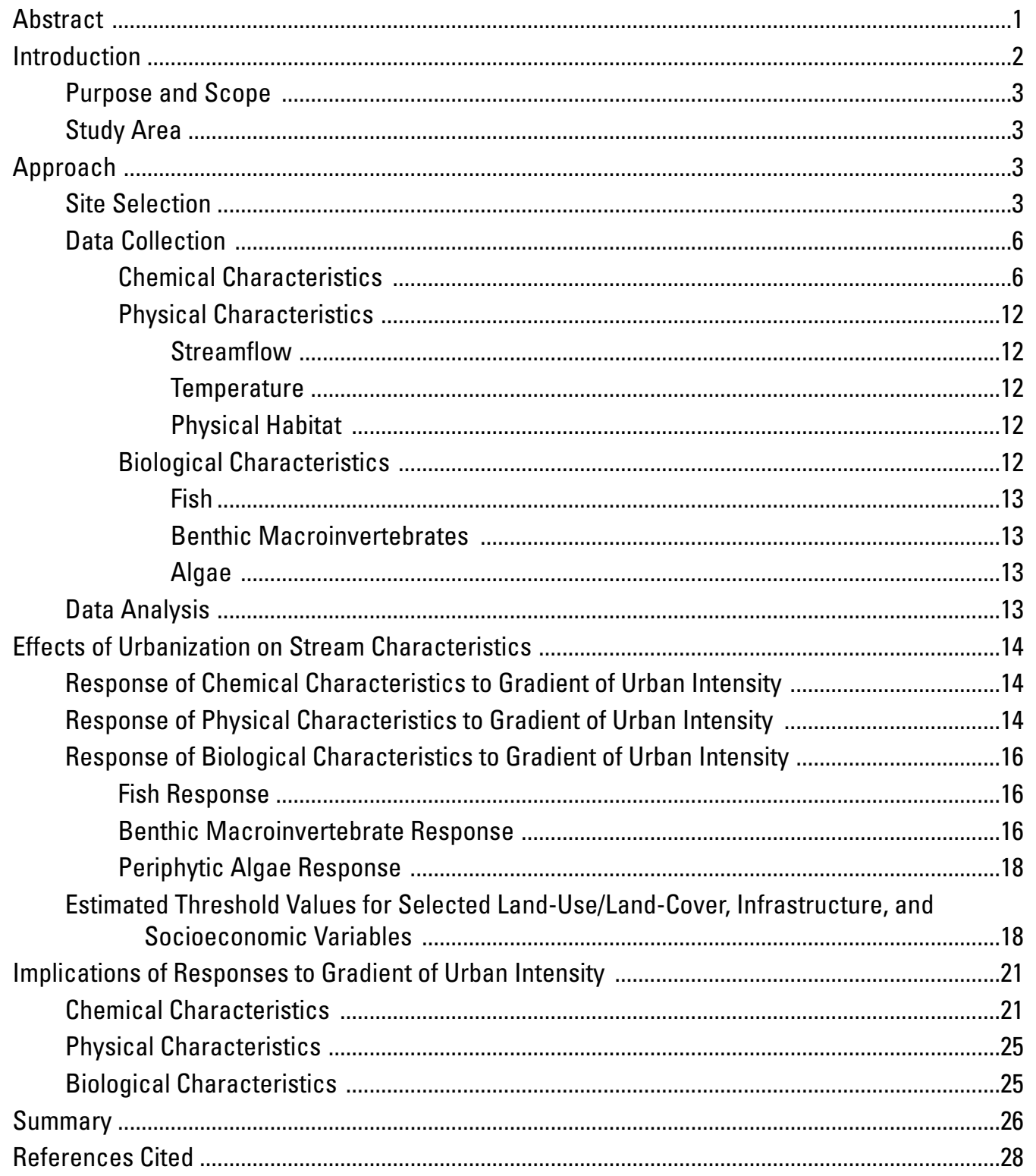

\section{Figures}

1-4. Maps showing:

1. Major river basins of Texas and Texas Blackland Prairie level III ecoregion ..........4

2. Urban land use/land cover in and near the Dallas-Fort Worth metropolitan area, Texas, 1992 and 2001

3. Candidate subbasins in (or nearly in) the area defined by the intersection of the Trinity River Basin and the Northern Blackland Prairie in and near the Dallas-Fort Worth metropolitan area, Texas 
4. Selected subbasins in and near the Dallas-Fort Worth metropolitan area, Texas, with reach (site) locations and urban intensity index scores

5-14. Graphs showing:

5. Potential toxicity, as measured in toxic equivalents of 2,3,7,8-Tetrachloro- $p$ dioxin (TCDD) from semipermeable membrane device extracts, relative to urban intensity index with locally weighted scatterplot smoothing (LOWESS) smooth for sites in and near the Dallas-Fort Worth metropolitan area, Texas

6. Potential toxicity, as measured in toxic equivalents of 2,3,7,8-Tetrachloro- $p$ dioxin (TCDD) from semipermeable membrane device extracts, relative to urban intensity index with pre- and post-threshold regression lines for sites in and near the Dallas-Fort Worth metropolitan area, Texas

7. The metric (index) Mxl_25 (maximum duration of low-flow pulses less than the 25th percentile of streamflow) relative to urban intensity index with locally weighted scatterplot smoothing (LOWESS) smooth for sites in and near the Dallas-Fort Worth metropolitan area, Texas

8. . The metric (index) Mxl_25 (maximum duration of low-flow pulses less than the 25th percentile of streamflow) relative to urban intensity index with preand post-threshold regression lines for sites in and near the Dallas-Fort Worth metropolitan area, Texas

9. The benthic macroinvertebrate metric Margalef's richness relative to urban intensity index with locally weighted scatterplot smoothing (LOWESS) smooth for sites in and near the Dallas-Fort Worth metropolitan area, Texas

10. The benthic macroinvertebrate metric Margalef's richness relative to urban intensity index with pre- and post-threshold regression lines for sites in and near the Dallas-Fort Worth metropolitan area, Texas

11. The periphytic algae metric (index) OT_VL_DP, an index of tolerance to low dissolved oxygen, relative to urban intensity index with locally weighted scatterplot smoothing (LOWESS) smooth for sites in and near the Dallas-Fort Worth metropolitan area, Texas

12. The periphytic algae metric (index) OT_VL_DP, an index of tolerance to low dissolved oxygen, relative to urban intensity index with pre- and postthreshold regression lines for sites in and near the Dallas-Fort Worth metropolitan area, Texas

13. The periphytic algae metric (index) ON_NH_DP, an index of the presence of nitrogen heterotrophic algae that respond to organic nitrogen concentrations, relative to urban intensity index with locally weighted scatterplot smoothing (LOWESS) smooth for sites in and near the Dallas-Fort Worth metropolitan area, Texas

14. The periphytic algae metric (index) ON_NH_DP, an index of the presence of nitrogen heterotrophic algae that respond to organic nitrogen concentrations, relative to urban intensity index with pre- and post-threshold regression lines for sites in and near the Dallas-Fort Worth metropolitan area, Texas $\mathrm{s}$

\section{Tables}

1. Land-use/land-cover, infrastructure, and socioeconomic variables for subbasins in and near the Dallas-Fort Worth metropolitan area, Texas, used to calculate urban intensity index for each subbasin 
2. Descriptive information and data-collection activities for sites and subbasins in and near the Dallas-Fort Worth metropolitan area, Texas

3. Spearman's rho correlation coefficients significant at the .05 level for correlation between chemical, physical, and biological variables and urban intensity index for reaches and subbasins in and near the Dallas-Fort Worth metropolitan area, Texas

4. Statistics associated with chemical and physical variables that showed a significant linear response or a threshold response to the urban intensity index for reaches and subbasins in and near the Dallas-Fort Worth metropolitan area, Texas

5. Statistics associated with biological variables (qualitative multi-habitat and richest targeted habitat benthic macroinvertebrate variables) that showed a significant linear response or a threshold response to the urban intensity index for reaches and subbasins in and near the Dallas-Fort Worth metropolitan area, Texas

6. Statistics associated with periphytic algae variables that showed a significant linear response or a threshold response to the urban intensity index for reaches and subbasins in and near the Dallas-Fort Worth metropolitan area, Texas

7. Values of land-use/land-cover, infrastructure, and socioeconomic variables for threshold values of physical and biological variables that showed significant threshold response to urban intensity index for subbasins in and near the DallasFort Worth metropolitan area, Texas

\section{Conversion Factors and Datum}

\section{SI to Inch/Pound}

\begin{tabular}{lcl}
\hline \multicolumn{1}{c}{ Multiply } & By & \multicolumn{1}{c}{ To obtain } \\
\hline & Length & \\
\hline centimeter $(\mathrm{cm})$ & 0.3937 & inch (in.) \\
kilometer $(\mathrm{km})$ & 0.6214 & mile $(\mathrm{mi})$ \\
meter $(\mathrm{m})$ & 3.281 & foot $(\mathrm{ft})$ \\
micrometer $(\mu \mathrm{m})$ & $3.937 \times 10^{-5}$ & inch (in.) \\
millimeter $(\mathrm{mm})$ & 0.03937 & inch (in.) \\
\hline & Area & \\
\hline square kilometer $\left(\mathrm{km}^{2}\right)$ & 0.3861 & square mile $\left(\mathrm{mi}^{2}\right)$ \\
\hline Volume & \\
\hline milliliter $(\mathrm{mL})$ & 0.034 & ounce, fluid (fl. oz) \\
\hline gram $(\mathrm{g})$ & Mass & \\
\hline
\end{tabular}

\section{Datum}

Horizontal coordinate information is referenced to North American Datum of 1983 (NAD 83). 
Blank Page 


\title{
Effects of Urbanization on the Chemical, Physical, and Biological Characteristics of Small Blackland Prairie Streams in and Near the Dallas-Fort Worth Metropolitan Area, Texas
}

\author{
By J. Bruce Moring
}

\begin{abstract}
In 2001, the U.S. Geological Survey National Water Quality Assessment Program began a series of studies in the contiguous United States to examine the effects of urbanization on the chemical, physical, and biological characteristics of streams. Small streams in the Texas Blackland Prairie level III ecoregion in and near the Dallas-Fort Worth metropolitan area were the focus of one of the studies. The principal objectives of the study, based on data collected in 2003-04 from 28 subbasins of the Trinity River Basin, were to (1) define a gradient of urbanization for small Blackland Prairie streams in the Trinity River Basin on the basis of a range of urban intensity indexes (UIIs) calculated using land-use/land-cover, infrastructure, and socioeconomic characteristics; (2) assess the relation between this gradient of urbanization and the chemical, physical, and biological characteristics of these streams; and (3) evaluate the type of relation (that is, linear or nonlinear, and whether there was a threshold response) of the chemical, physical, and biological characteristics of these streams to the gradient of urbanization. Of 94 water-chemistry variables and one measure of potential toxicity from a bioassay, the concentrations of two pesticides (diazinon and simazine) and one measure of potential toxicity (P450RGS assay) from compounds sequestered in semipermeable membrane devices were significantly positively correlated with the UII. No threshold responses to the UII for diazinon and simazine concentrations were observed over the entire range of the UII scores. The linear correlation for diazinon with the UII was significant, but the linear correlation for simazine with the UII was not. No statistically significant relations between the UII and concentrations of suspended sediment, total nitrogen, total phosphorous, or any major ions were indicated. Eleven of 59 physical variables from streamflow were significantly correlated with the UII. Temperature was not significantly correlated with the UII, and none of the physical habitat measurements were significantly correlated with the UII. Seven physical variables categorized as streamflow flashiness
\end{abstract}

metrics were significantly positively correlated with the UII, two of which showed a linear but not a threshold response to the UII. Four flow-duration metrics were significantly negatively correlated with the UII, of which two showed a linear response to the UII, one showed a threshold response, and one showed neither. None of the fish metrics were significantly correlated with the UII in the Blackland Prairie streams. Two qualitative multi-habitat benthic macroinvertebrate metrics, predator richness and percentage filterer-collector richness, were significantly correlated with the UII; predator richness was negatively correlated with the UII, and percentage filterercollector richness was positively correlated with the UII. No threshold response to the UII was observed for either metric, but both showed a significant linear response to the UII. Three richest targeted habitat (RTH) benthic macroinvertebrate metrics, Margalef's richness, predator richness, and omnivore richness were significantly negatively correlated with the UII. Margalef's richness was the only RTH metric that indicated a threshold response to the UII. The majority of unique taxa collected in the periphytic algae samples were diatoms. Six RTH periphytic algae metrics were correlated with the UII and five of the six showed no notable threshold response to the UII; but all five showed significant linear responses to the UII. Only the metric OT_VL_DP, which indicates the presence of algae that are tolerant of low dissolved oxygen conditions, showed a threshold response to the UII. Six depositional target habitat periphytic algae metrics were correlated with the UII, five of which showed no threshold response to the UII; three of the five showed significant linear responses to the UII, one showed a borderline significant response, and one showed no significant response. Only the nitrogen heterotrophic metric ON_NH_DP, which indicates the presence of algal taxa tolerant to elevated concentrations of organically bound nitrogen, showed a threshold response. The land-use/land-cover, infrastructure, and socioeconomic variables that were most strongly correlated with the UII are mean percentage impervious surface, percentage developed, road density, and density of housing units. The magnitudes of the estimated threshold 
values of all four land-use/land-cover, infrastructure, and socioeconomic variables, estimated by regression of each variable on the UII, for each of the four physical and biological variables ranked the same as the threshold values of the UII for the physical and biological variables.

\section{Introduction}

Aquatic ecosystems provide important benefits such as freshwater for agriculture, waste disposal, recreational activities, and aesthetic enjoyment (Petts, 1989). Human population growth has affected aquatic ecosystems including streams (Postel, 2000; Paul and Meyer, 2001). Urbanization has resulted in the conversion of rural lands to urban lands, and freshwater ecosystems have been subjected to increasing stress from this conversion with a variety of consequences for ecological processes (McDonnell and Picket, 1990; Sala and others, 2000). Freshwater stream ecosystems are vulnerable to urban development because the majority of major urban centers are on or near major waterways (Sala and others, 2000).

The majority of the world's population growth through 2030 is expected to occur through the expansion of existing urban areas (United Nations, 2004). Much of the expansion in urban areas is occurring through the development of rural lands into what has been referred to as exurban lands (Johnson, K.M., 1998; Brown and others, 2005). There has been a five-fold increase in exurban development in the United States since 1950 (Brown and others, 2005), accounting for the majority of what is often termed urban or suburban sprawl. The effects of urban development on streams are disproportionate to those of agriculture, with each square kilometer of urban land impairing 0.154 kilometer of stream compared to 0.046 kilometer of stream impaired for each square kilometer of agriculture (U.S. Environmental Protection Agency, 1997).

Streams in urban settings can be influenced in a number of ways. Several studies have documented the chemical, physical, or biological responses of freshwater streams to urbanization (Wang and others, 2000; Paul and Meyer, 2001; Walsh and others, 2001). The chemical condition of streams in the urban environment can be influenced by runoff from a variety of sources such as rooftops, parking lots, golf courses, construction sites, and residential areas. Additional sources that can influence the chemical condition of urban streams include wastewater treatment plants, septic systems, and industrial discharges. Concentrations of metals, nutrients, pesticides, and polycyclic aromatic hydrocarbons can be elevated in urban streams because of increased runoff from impervious surfaces and from wastewater treatment plant discharges (Klein, 1979; Ahel and others, 2000; Shinya and others, 2000).

Urbanization can affect the physical characteristics of a stream by influencing stream temperature, flow, and channel form. Water temperature in urban streams can be affected by a reduction in vegetative canopy over the stream (Sinokrot and Stefan, 1993) and by a reduction in base flow (LeBlanc and others, 1997). The effects of urbanization on stream hydrology include increased flashiness and a shorter duration of high flows (Poff and others, 1997). The duration, magnitude, frequency, and timing of streamflow can be altered by an increase in impervious surface in urban settings (Poff and others, 1997; U.S. Environmental Protection Agency, 1997; McMahon and others, 2003). These changes in streamflow can influence channel morphology and riparian habitat conditions. The effects of urbanization on channel form have been demonstrated by several studies (Gregory and others, 1992; Booth and Jackson, 1997; Jacobson and others, 2001). Urbanization of the surrounding watershed can lead to an increase in soil disturbance that can cause an increase in the loading of sediment to streams. Large areas of impervious cover in urbanized regions can increase the erosion of channel features by increasing storm runoff, which results in channel incision and widening (Whitlow and Gregory, 1989; Trimble, 1997).

The effects of urbanization on fish are less well known than the effects of urbanization on benthic macroinvertebrates (Meador and others, 2005). However, several studies indicate that fish assemblages in urban streams are less diverse than in non-urban streams (Weaver and Garman, 1994). In addition, urbanization has been associated with an increase in alien fish species (DeVivo, 1996), an increase in the number of tolerant fish species (Wang and others, 2000), a loss of fish habitat (Martin and others, 1986), and changes in trophic position (Vannote and others, 1980).

The effects of urbanization on benthic macroinvertebrates have been well documented (Jones and Clark, 1987; Horner and others, 1997; Yoder and others, 1999; Volstad and others, 2003). Benthic macroinvertebrate taxa richness typically decreases with urbanization (Kennen and Ayers, 2002; Roy and others, 2003), percentage of tolerant taxa increases with urbanization (Roy and others, 2003), and diversity index values decrease with urbanization (Paul and Meyer, 2001).

Algae in streams commonly are of public concern only if excessive algal populations reduce the aesthetic value of streams, clog water supplies, or cause secondary pollution (Potapova and others, 2005). Some studies have reported a decline in the diversity of algae (Nather Khan, 1991) and algal biomass (Taylor and others, 2004) in urban streams.

The effects of urbanization on freshwater stream ecosystems are well documented. However, an understanding of the complexities associated with the intensity of urbanization and its influence on stream ecosystems is lacking (Karr and Chu, 1999). Measures of urbanization often rely on single variables such as impervious cover, population density, or urban land cover (Arnold and Gibons, 1996). An alternative to the single-variable approach is to characterize urbanization by integrating the multiple aspects of human influence on the urban landscape (McMahon and Cuffney, 2000; Falcone and others, 2007). This approach relies on developing 
an index of urban intensity that integrates information on the land-use/land-cover, infrastructure, and socioeconomic conditions for a watershed.

In 2001, the U.S. Geological Survey (USGS) National Water Quality Assessment (NAWQA) Program began a series of studies in the contiguous United States to examine the effects of urbanization on the chemical, physical, and biological characteristics of streams (Couch and Hamilton, 2002) using the index of urban intensity approach developed by McMahon and Cuffney (2000). Six NAWQA Study Units were selected, one of which was the Trinity River Basin Study Unit in Texas. Small streams in the Texas Blackland Prairie level III ecoregion (Omernick, 1987; Griffith and others, 2004) in and near the Dallas-Fort Worth metropolitan area (DFW area) were the focus of the study. The principal objectives of the study were to (1) define a gradient of urbanization, or gradient of urban intensity, for small Blackland Prairie streams in the Trinity River Basin on the basis of a range of urban intensity indexes (UIIs) calculated using land-use/land-cover, infrastructure, and socioeconomic characteristics; (2) assess the relation between this gradient of urbanization and the chemical, physical, and biological characteristics of these streams; and (3) evaluate the type of relation (that is, linear or nonlinear, and whether there was a threshold response) of the chemical, physical, and biological characteristics of these streams to the gradient of urbanization.

\section{Purpose and Scope}

This report describes the effects of urbanization on the chemical, physical, and biological characteristics of small Blackland Prairie streams in and near the DFW area on the basis of data collected in 2003-04. Twenty-eight subbasins ranging from about 25 to 290 square kilometers in drainage area were selected for this study. All subbasins selected are in the Texas Blackland Prairie level III ecoregion to minimize subbasin differences in surficial geology, climate, and elevation. Land-use/land-cover, infrastructure, and socioeconomic characteristics of each subbasin were determined and used to calculate an UII for each subbasin. Landuse/land-cover features were determined for a stream segment at the terminus or node of each subbasin; segment length was based on subbasin drainage area. A reach at least 150 meters long within the selected segment and upstream from the terminus of each subbasin was selected for data collection. Reaches were selected to minimize betweenreach differences in riparian vegetation, channel morphology, and substrate of the streambed. Chemical characteristics evaluated in each reach included sulfate, chloride, nutrients, pesticides, dissolved and particulate carbon, and suspended sediment; the physical characteristics included stream stage (to compute streamflow), water temperature, and stream habitat; biological characteristics included fish, benthic macroinvertebrate, and algae communities.

\section{Study Area}

The Texas Blackland Prairie level III ecoregion (fig. 1) comprises three subregions, the Northern Blackland Prairie, the Southern Blackland Prairie, and the third subregion consisting of a few small areas of each of the first two subregions immediately adjacent to major streams and called Floodplains and Low Terraces (not shown in fig. 1). The Blackland Prairie ecoregion is characterized by rolling to level plains underlain by Cretaceous-age chalk, marl, limestone, and shale (Texas Parks and Wildlife Department, 2007). The natural vegetation of the Texas Blackland Prairie is dominated by little bluestem. Indiangrass, big bluestem, switchgrass, and eastern gamagrass are major species. Among woody species are hackberry, oak, elm, cottonwood, and pecan (Soil Conservation Service, 1981). The Texas Blackland Prairie has more land in cultivation than adjacent ecoregions in Texas; however, much of the land was urbanized during the last one-half of the 20th century (Ulery and others, 1993).

The DFW area is in the approximate center of the area defined by the intersection of the Trinity River Basin and the Northern Blackland Prairie (hereinafter, Blackland Prairie) (fig. 1). The DFW area ranges in elevation from about 150 to 250 meters above sea level (National Climatic Data Center, 2008). Average annual (1971-2000) precipitation is 882 millimeters. Much of the annual precipitation results from thunderstorms that occur throughout the year but are most frequent in the spring. The population of the DFW area was about 4.0 million in 1990 and increased to about 5.2 million in 2000 (U.S. Census Bureau, 2001). The increase in population is reflected by the increase in urban land cover between 1992 and 2001 (fig. 2).

\section{Approach}

\section{Site Selection}

Stream nodes were selected to account for all subbasins greater than 20 and less than 300 square kilometers in (or nearly in) the area where the Trinity River Basin intersects the Blackland Prairie (fig. 1). Stream nodes that were considered inappropriate because they were in impounded water bodies, lacked road access, or were otherwise inaccessible were excluded. Retained stream nodes and associated subbasins were delineated using a 30-meter USGS National Elevation Dataset (U.S. Geological Survey, 2008) to approximate second- to fifth-order streams. Percentage land use/land cover, impervious cover, topography, environmental landscape, infrastructure, and socioeconomic information were determined for each subbasin using Geographic Information System (GIS) datasets from the area delineated for each subbasin. Falcone and others (2007) provides a description of data sources and GIS methods used for all GIS-derived variables. In addition, 


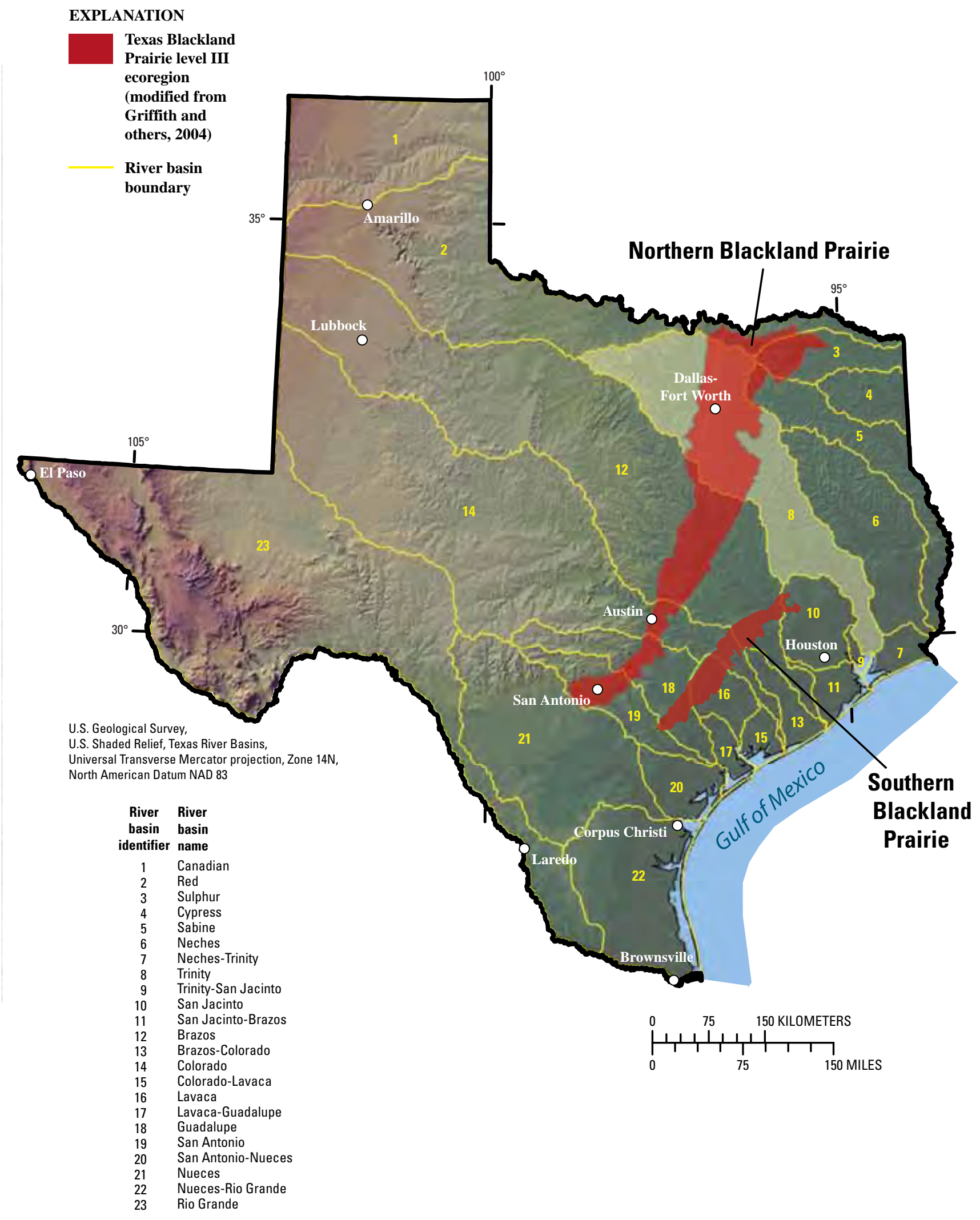

Figure 1. Major river basins of Texas and Texas Blackland Prairie level III ecoregion. 

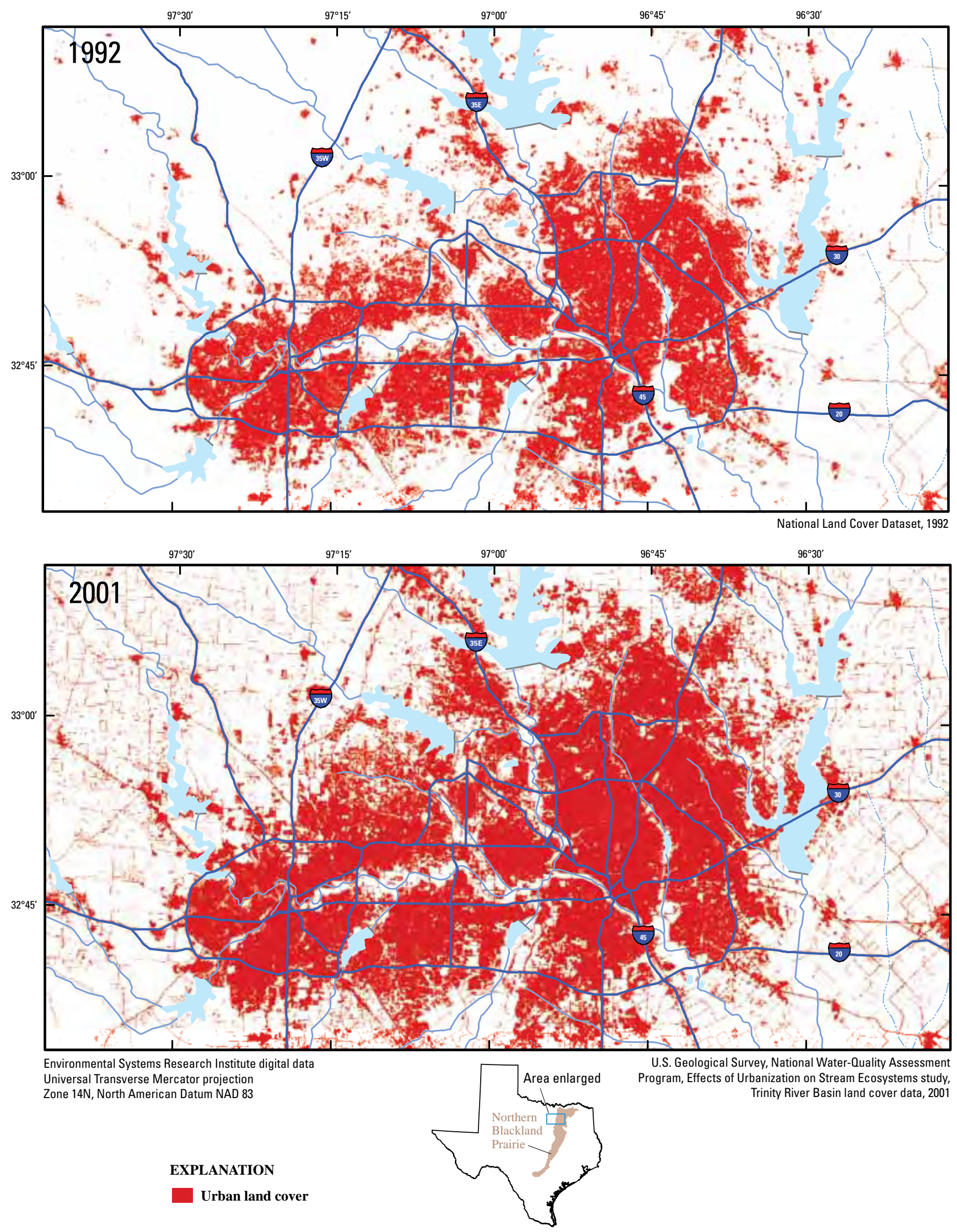

Figure 2. Urban land use/land cover in and near the Dallas-Fort Worth metropolitan area, Texas, 1992 and 2001. 
land-use/land-cover features were determined for a 200-meterwide (approximately 100 meters on each side of the stream centerline) riparian buffer zone over the length of a stream segment upstream from each subbasin node. Segment length was based on subbasin drainage area and was computed as $\log _{10}$ (drainage area) times 1,000 (Falcone and others, 2007).

Surficial geology and soil characteristics for each subbasin were evaluated using a K-means cluster analysis (StatSoft, Inc., 2006) to screen a candidate group of subbasins for a subset of homogeneous subbasins based on these physical characteristics. A candidate group of 56 subbasins was selected (fig. 3) for further consideration largely on the basis of clustering or grouping of subbasins using the soil variables, percentage fines, and infiltration rates. A site at the node of each of the 56 subbasins was visited to determine whether the site was suitable for stream-reach selection and sample collection. Sites were evaluated for accessibility for sampling, similar channel form, bed substrate, native riparian vegetation, and occurrence of like geomorphic channel units such as riffles, runs, and pools to minimize between-site variability.

An urban intensity index (UII) was calculated for each of the 56 candidate subbasins using the procedure described by McMahon and Cuffney (2000). Land-use/land-cover, infrastructure, and socioeconomic variables that were correlated with population density (absolute value of Spearman's rho equal to or greater than .50) were retained for analysis. A description of the land-use/land-cover, infrastructure, and socioeconomic variables used to produce the UII is in Falcone and others (2007). Nine land-use/land-cover, nine buffer land-use/land-cover, five infrastructure, and 26 socioeconomic variables (table 1) were used to calculate a UII for each subbasin. In short, the procedure involved (1) adjusting variables for basin size and units, (2) range-standardizing all variables to a range of 0 to 100 , (3) adjusting variables that negatively correlated with population density so that all variables are positively correlated with population density, (4) calculating the UII for each subbasin as the average of the transformed variables, and (5) sorting the UII so the range of urban intensity is 0 to 100 (that is, low to high).

A major goal of this study was to establish a gradient of urban intensity across the landscape as a surrogate for evaluating the effects of urbanization at one or more sites over time (Cuffney and others, 2005). The 56 candidate reaches (one for each candidate subbasin) were reduced to a predetermined target of 30 reaches, each at the node of a subbasin, that were most similar in channel form, bed substrate, and native riparian vegetation. The 30 reaches and associated subbasins selected provided a gradient of urbanization as represented by the range of UII scores sorted from smallest to largest. Two reaches and subbasins were eliminated because of concerns about the influence of small downstream impoundments, which resulted in a final set of 28 reaches (hereinafter, reaches synonymous with sites) (table 2) and 28 subbasins (fig. 4).

At each of the 28 sites, a sampling reach was identified for the collection of chemical, physical, and biological data. Where possible, each reach was located upstream from any structures such as a road bridge that might affect downstream channel conditions. If the reach could not be located upstream from a structure, the reach was located at least one reach length downstream from the structure. A section of stream was chosen for each reach that contained at least two or more geomorphic channel units such as a riffle, run, or pool. Reach length was determined as the longer of 20 times wetted channel width or 150 meters. The upstream and downstream boundaries of the reach were marked using a rebar stake and surveyor's cap, and a detailed description of the location of the reach in relation to access from the nearest road was recorded.

\section{Data Collection}

The data-collection methods used in this study were standard USGS or NAWQA methods (U.S. Geological Survey, variously dated; Fitzpatrick and others, 1998; Moulton and others, 2002). Nonstandard procedures used in this study included the measurement of stream stage and the use of semipermeable membrane devices (SPMDs) to evaluate the potential for stream toxicity.

\section{Chemical Characteristics}

All chemistry samples were collected over a 7-month period prior to the collection of biological data to characterize antecedent water-quality conditions. Water-chemistry samples were collected during November 2003-May 2004 at 27 of the 28 sites (table 2). Samples were not collected at the Little Pin Oak Creek site because of a lack of adequate flow during scheduled sampling. Nine of the 27 reaches were designated as "high-intensity" sampling reaches because chemistry samples were collected monthly five to six times during the 7-month period prior to biological assessments. The nine highintensity reaches were selected to cover the full range of the UII gradient. Water-chemistry samples were collected twice at the remaining 18 reaches during base-flow conditions in early winter and late spring in an attempt to minimize the effects of variable streamflow on water chemistry.

All water-chemistry samples were analyzed for sulfate, chloride, nutrients, pesticides, dissolved and particulate organic carbon, and suspended sediment. All samples were collected using standardized depth- and width-integrated sample-collection methods and onsite sample processing procedures (U.S. Geological Survey, variously dated). Blank, duplicate, and spike samples were collected for quality control during the study. All samples, except for the suspended sediment samples, were submitted to the USGS National Water Quality Laboratory in Denver, Colo., for analysis following methods described in Fishman and Friedman (1989), Brenton and Arnett (1993), Fishman (1993), and Zaugg and others (1995). Suspended sediment samples were analyzed by the USGS Louisiana Water Science Center sediment laboratory in Baton Rouge, La. In all, 94 water-chemistry constituents were measured for each reach. The water-chemistry 


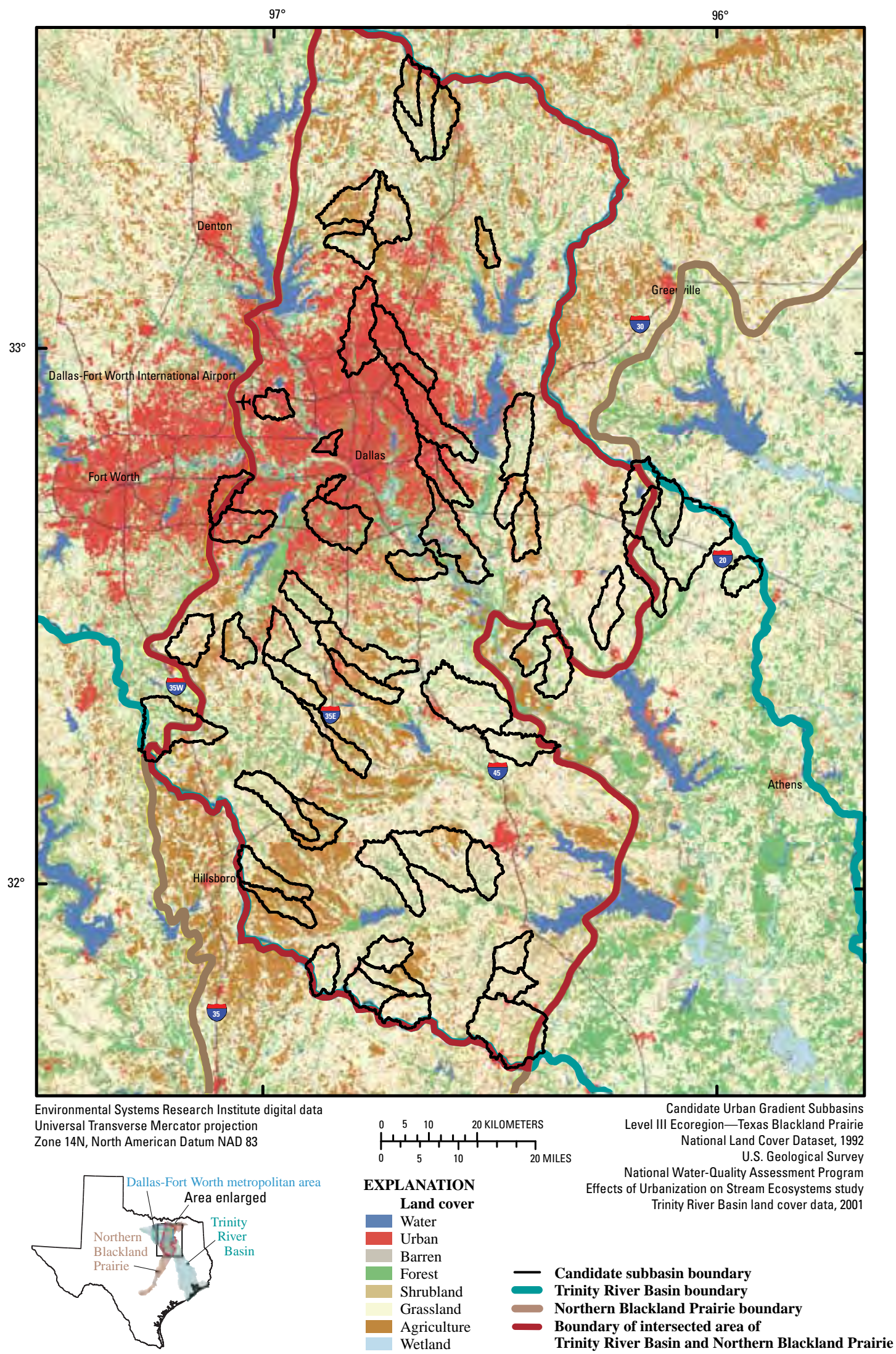

Figure 3. Candidate subbasins in (or nearly in) the area defined by the intersection of the Trinity River Basin and the Northern Blackland Prairie in and near the Dallas-Fort Worth metropolitan area, Texas. 


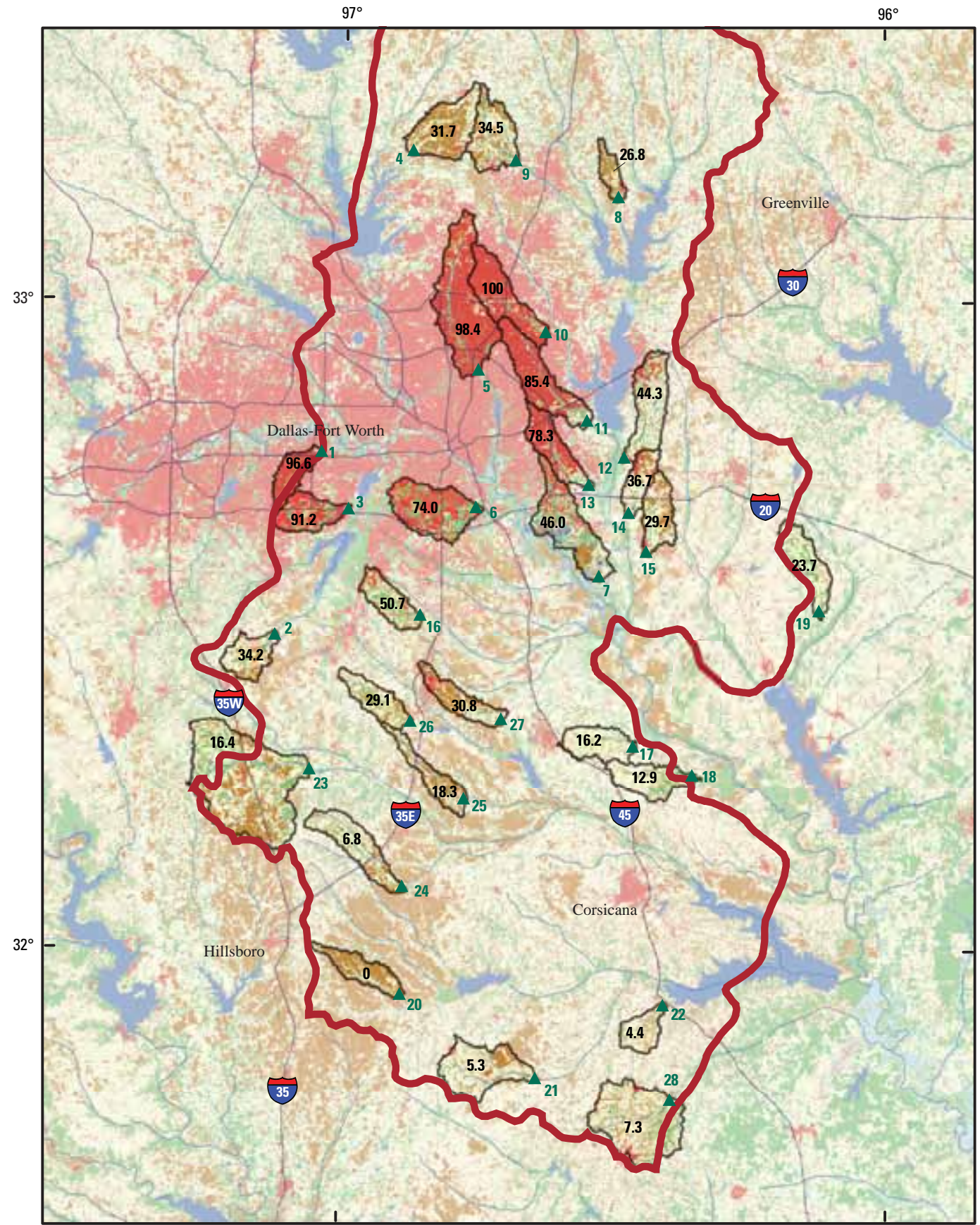

Environmental Systems Research Institute digital data Universal Transverse Mercator projection

Final Urban Gradient Subbasins Zone $14 \mathrm{~N}$, North American Datum NAD 83

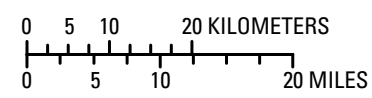
National Land Cover Dataset, 1992 U.S. Geological Survey National Water-Quality Assessment Program Effects of Urbanization on Stream Ecosystems study

EXPLANATION
Land cover
Water
Urban
Barren
Forest
Shrubland
Grassland
Agriculture
Wetland
Trinity River Basin land cover data, 2001

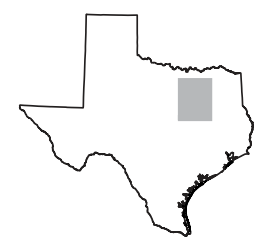

Figure 4. Selected subbasins in and near the Dallas-Fort Worth metropolitan area, Texas, with reach (site) locations and urban intensity index scores. 
Table 1. Land-use/land-cover, infrastructure, and socioeconomic variables for subbasins in and near the Dallas-Fort Worth metropolitan area, Texas, used to calculate urban intensity index for each subbasin.

[Variables from Falcone and others (2007) ${ }^{1}$; for this table, subbasin synonymous with basin and watershed; rho PD, Spearman's rho for correlation of variable with subbasin population density; rho DA, Spearman's rho for correlation of variable with subbasin drainage area]

\begin{tabular}{|c|c|c|c|c|}
\hline Variable type & Variable description & $\begin{array}{c}\text { Variable } \\
\text { name }\end{array}$ & $\begin{array}{l}\text { Rho } \\
\text { PD }\end{array}$ & $\begin{array}{c}\text { Rho } \\
\text { DA }\end{array}$ \\
\hline \multirow{6}{*}{$\begin{array}{l}\text { Land use/land } \\
\text { cover }\end{array}$} & Urban development (square miles) & NLCD1_2 & .827 & .495 \\
\hline & Shrubland (square miles) & NLCD1_5 & -.845 & -.001 \\
\hline & Herbaceous planted/cultivated (square miles) & NLCD1_8 & -.600 & .333 \\
\hline & Developed (percentage of basin area) & P_NLCD1_2 & .909 & .161 \\
\hline & Herbaceous planted/cultivated (percentage of basin area) & P_NLCD1_8 & -.621 & -.250 \\
\hline & Mean percentage impervious surface & NLCD_IS & .926 & .179 \\
\hline \multirow{5}{*}{$\begin{array}{l}\text { Riparian buffer } \\
\text { land use/ } \\
\text { land cover }\end{array}$} & Riparian buffer developed (square miles) & NLCD1_B2 & .736 & .327 \\
\hline & Riparian buffer shrubland (square miles) & NLCD1_B5 & -.858 & .057 \\
\hline & Riparian buffer herbaceous upland natural/seminatural (square miles) & NLCD1_B7 & -.768 & .152 \\
\hline & Herbaceous planted/cultivated (percentage of basin area) & P_NLCD1_B8 & -.623 & -.273 \\
\hline & Mean percentage impervious surface in buffer & NLCD_BIS & .861 & .013 \\
\hline \multirow[t]{5}{*}{ Infrastructure } & Road density in watershed & ROADDEN & .943 & .143 \\
\hline & Road area index in watershed (miles) & RDARINDX & .939 & .133 \\
\hline & Road traffic index in watershed (miles) & RDTRINDX & .932 & .151 \\
\hline & Number of Toxics Release Inventory sites in watershed & TRICOUNT & .767 & .147 \\
\hline & Density of Toxics Release Inventory sites in watershed & TRIDEN & .767 & .061 \\
\hline \multirow[t]{19}{*}{ Socioeconomic } & Socioeconomic index 2 & SEI_2 & .864 & .115 \\
\hline & Socioeconomic index 3 & SEI_3 & -.842 & -.033 \\
\hline & Socioeconomic index 4 & SEI_4 & -.689 & -.353 \\
\hline & Percentage of occupied housing units using wood as fuel & PHWOOD & -.726 & .985 \\
\hline & Density of housing units (housing units per square kilometer) & HUDEN & .985 & .154 \\
\hline & Proportion of housing units occupied by persons older than 65 years & POCC_G65 & -.599 & .126 \\
\hline & Proportion of population living in rural area & PPRURAL & -.921 & -.070 \\
\hline & Proportion of population race $=$ white & PPWHITE & -.534 & -.300 \\
\hline & Proportion of population race $=$ Asian & PPASIA & .769 & .168 \\
\hline & Proportion of households occupied by less than three people & PHO_L3P & -.629 & .120 \\
\hline & Proportion of citizens born in United States & PC_US & -.522 & -.184 \\
\hline & Proportion of citizens born in State of residence & PC_INST & -.774 & -.085 \\
\hline & Proportion of citizens born in other U.S. States (2000 census block-group based) & PC_OUTST & .591 & -.019 \\
\hline & Proportion of housing units occupied & P_OCCUPY & .637 & -.092 \\
\hline & Proportion of housing units vacant & P_VACANT & -.658 & .083 \\
\hline & Proportion of households occupied by two persons & PH_2PERS & -.595 & .115 \\
\hline & Proportion of housing units built prior to 1949 (1939-49) & PHU_G50 & -.789 & .029 \\
\hline & Proportion of housing units built prior to 1939 & PHU_G60 & -.861 & -.043 \\
\hline & Median family household income & MNFAMINC & .586 & .009 \\
\hline
\end{tabular}

\footnotetext{
${ }^{1}$ With some modification of variable type and variable description nomenclature.
} 
Table 2. Descriptive information and data-collection activities for sites and subbasins in and near the Dallas-Fort Worth metropolitan area, Texas.

[USGS, U.S. Geological Survey; SPMD, semipermeable membrane device; +, indicates data-collection activity for site and subbasin; --, not collected or not recovered; ++, high-intensity water-chemistry site]

\begin{tabular}{|c|c|c|c|c|c|c|c|c|c|}
\hline $\begin{array}{c}\text { Reach } \\
\text { (site) } \\
\text { identi- } \\
\text { fier } \\
\text { (fig. 4) }\end{array}$ & $\begin{array}{l}\text { USGS station name } \\
\text { and number }\end{array}$ & $\begin{array}{c}\text { Urban } \\
\text { intensity } \\
\text { index } \\
\text { (for } \\
\text { subbasin) }\end{array}$ & $\begin{array}{c}\text { Site } \\
\text { latitude } \\
\text { (decimal } \\
\text { degrees) }\end{array}$ & $\begin{array}{c}\text { Site } \\
\text { longitude } \\
\text { (decimal } \\
\text { degrees) }\end{array}$ & $\begin{array}{c}\text { Drainage } \\
\text { area of } \\
\text { subbasin } \\
\text { (square } \\
\text { kilometers) }\end{array}$ & $\begin{array}{c}\text { Water } \\
\text { chem- } \\
\text { istry }\end{array}$ & $\begin{array}{c}\text { SPMD } \\
\text { deploy- } \\
\text { ment }\end{array}$ & $\begin{array}{c}\text { Physical } \\
\text { assess- } \\
\text { ment }\end{array}$ & $\begin{array}{c}\text { Biolog- } \\
\text { ical } \\
\text { assess- } \\
\text { ment }\end{array}$ \\
\hline 1 & $\begin{array}{l}\text { Johnson Creek near Duncan Perry Road, } \\
\text { Grand Prairie - } 08049490\end{array}$ & 96.6 & 32.767778 & -97.037500 & 43.23 & + & -- & + & + \\
\hline 2 & Mountain Creek near Venus - 08049580 & 34.2 & 32.490972 & -97.123065 & 51.96 & + & -- & + & + \\
\hline 4 & $\begin{array}{l}\text { Doe Branch at Fishtrap Road near Prosper - } \\
08052740\end{array}$ & 31.7 & 33.263889 & -96.881944 & 94.53 & ++ & + & + & + \\
\hline 5 & $\begin{array}{l}\text { White Rock Creek at Greenville Avenue, } \\
\text { Dallas - } 08057200\end{array}$ & 98.4 & 32.889292 & -96.756666 & 173.0 & ++ & -- & + & + \\
\hline 6 & $\begin{array}{l}\text { Fivemile Creek near Simpson Stuart Road, } \\
\text { Dallas - } 08057431\end{array}$ & 74.0 & 32.683333 & -96.750000 & 109.0 & ++ & + & + & + \\
\hline 9 & $\begin{array}{l}\text { Wilson Creek near Gray Branch Road near } \\
\text { McKinney - } 08059571\end{array}$ & 34.5 & 33.215556 & -96.690556 & 80.96 & + & + & + & + \\
\hline 10 & $\begin{array}{l}\text { Spring Creek at Naaman School Road near } \\
\text { Garland - } 08061536\end{array}$ & 100.0 & 32.954444 & -96.628611 & 91.09 & + & + & + & + \\
\hline 11 & $\begin{array}{l}\text { Duck Creek at Town East Blvd. near } \\
\text { Mesquite - } 08061740\end{array}$ & 85.4 & 32.816667 & -96.555000 & 102.3 & + & -- & + & + \\
\hline 12 & $\begin{array}{l}\text { Buffalo Creek near Trinity Road at Forney - } \\
08061780\end{array}$ & 44.3 & 32.752778 & -96.500000 & 88.16 & ++ & -- & + & + \\
\hline 13 & $\begin{array}{l}\text { South Mesquite Creek at Lawson Road near } \\
\text { Mesquite - } 08061952\end{array}$ & 78.3 & 32.713333 & -96.551111 & 64.62 & + & + & + & + \\
\hline 14 & $\begin{array}{l}\text { Mustang Creek at Farm to Market Road } \\
2757 \text { near Crandall - } 08061995\end{array}$ & 36.7 & 32.673333 & -96.473056 & 42.99 & + & + & + & + \\
\hline 19 & $\begin{array}{l}\text { Williams Creek near Farm to Market Road } \\
1836 \text { near Kemp - } 08062805\end{array}$ & 23.7 & 32.510833 & -96.127222 & 68.04 & + & -- & + & + \\
\hline 20 & $\begin{array}{l}\text { Bynum Creek near Farm to Market Road } \\
308 \text { near Malone - } 08063047\end{array}$ & 0 & 31.926389 & -96.890278 & 52.78 & + & + & + & + \\
\hline 21 & $\begin{array}{l}\text { Pin Oak Creek near Farm to Market Road } 73 \\
\text { near Coolidge - } 08063300\end{array}$ & 5.3 & 31.801944 & -96.636667 & 101.7 & + & -- & + & + \\
\hline 22 & $\begin{array}{l}\text { Little Pin Oak Creek near Interstate High- } \\
\text { way } 45 \text { near Richland - } 08063510\end{array}$ & 4.4 & 31.920000 & -96.409722 & 40.87 & -- & + & + & + \\
\hline 23 & $\begin{array}{l}\text { South Fork Chambers Creek near County } \\
\text { Road } 102 \text { near Maypearl - } 08063555\end{array}$ & 16.4 & 32.286944 & -97.088056 & 291.4 & ++ & + & + & + \\
\hline 24 & $\begin{array}{l}\text { Mill Creek at Lowell Road near Milford - } \\
08063565\end{array}$ & 6.8 & 32.098611 & -96.884444 & 80.37 & ++ & + & + & + \\
\hline 25 & $\begin{array}{l}\text { Big Onion Creek at Feaster Road near } \\
\text { Bardwell - } 08063574\end{array}$ & 18.3 & 32.233611 & -96.768889 & 52.91 & + & + & + & + \\
\hline 26 & $\begin{array}{l}\text { South Prong Creek at Farm to Market Road } \\
876 \text { near Waxahachie - } 08063595\end{array}$ & 29.1 & 32.349444 & -96.870833 & 53.41 & ++ & + & + & + \\
\hline 27 & $\begin{array}{l}\text { Mustang Creek at Moseley Road near } \\
\text { Ennis - } 08063692\end{array}$ & 30.8 & 32.352500 & -96.707222 & 55.84 & + & + & + & + \\
\hline 28 & $\begin{array}{l}\text { Tehuacana Creek at Rural Road } 27 \text { near } \\
\text { Wortham - } 08064695\end{array}$ & 7.3 & 31.772778 & -96.396389 & 164.7 & ++ & + & + & + \\
\hline
\end{tabular}


constituents and analytical results are listed in Giddings and others (2009). All concentrations reported at or less than laboratory reporting levels were converted to zero for data analysis and interpretation.

Water-chemistry samples for quality control consisted of field blanks, duplicates, and laboratory spikes. Ten field blanks, or about 12 percent of the number of environmental samples, were collected to account for contamination during sample collection, processing, and laboratory analysis. No constituents were detected in concentrations at or above the laboratory reporting levels in the field blank samples. Six duplicates were collected to evaluate variability in concentration that could be attributed to sample collection, sample processing, or laboratory analysis. The mean relative percentage difference (RPD) between the concentration of the environmental sample and that of its paired duplicate was greater than 10 percent for nitrite nitrogen, inorganic carbon (suspended sediment fraction), iprodione, tebuthurion, terbufos, prometon, isofenphos, ethion monoxon, 3,4-dichloroanaline, and 2-ethyl-6 methylanaline. A duplicate sample pair with RPD greater than 10 percent indicates within-site variability in concentration. One laboratory spike sample was analyzed to assess bias in the percentage recovery of each pesticide during laboratory analysis. Laboratory spike recoveries were less than 50 percent for cis-permethrin, dicrotophos, dimethoate, and fenamiphos. Mean percentage recovery from the laboratory spikes for all pesticides was 90 percent. Minimum percentage recovery from the laboratory spikes for all pesticides was 25 percent and the maximum percentage recovery was 132 percent. A more detailed description of the type of qualitycontrol samples used and all of the quality-control data for this and other, similar NAWQA studies are in Sprague and others (2007).

SPMDs were installed at the 28 sites for 4- or 6-week periods in May and June 2004. The intent was to deploy each SPMD for 6 weeks, but some SPMDs were recovered after 4 weeks because of very low to no-flow conditions at some sites. The SPMD used is this study was a 15.2-centimeter strip of low-density polyethylene tubing filled with about 1 milliliter of a purified lipid such as triolein (Huckins and others, 1993). The SPMD is a passive sampling device that allows the passage of hydrophobic organic compounds through 10angstrom-diameter cavities in the polyethylene tubing. Only those hydrophobic organic compounds that are in the aqueous phase, have a log octanol-to-water partition coefficient of 3.0 or greater, and are readily bioavailable will concentrate inside the SPMD (Huckins and others, 1990). Each SPMD was installed mid-channel and positioned at a depth to keep the SPMD submerged during the period of deployment. Water temperature was recorded at installation and recovery.

The SPMDs at seven sites were lost because of high flows or vandalism and thus not recovered (table 2). The SPMDs that were recovered at the end of the deployment period were submitted to Environmental Sampling Technologies (EST) in St. Joseph, Mo., for the separation of contaminant residues by dialysis using an organic solvent (Huckins and others, 1990). Ampulized extracts from the dialysis procedure were sent by EST to the USGS Columbia Environmental Research Center in Columbia, Mo., for an ultraviolet fluorescent scan for quantization of polycyclic aromatic hydrocarbons (PAHs) (Johnson and others, 2004) and a Microtox ${ }^{\circledR}$ bioassay (Johnson, B.T., 1998). The Microtox bioassay measures the inhibition of light production of a photoluminescent bacterium after exposure to the SPMD extract. The enzymatic pathway that produces the light in these bacteria can be inhibited by a number of organic compounds commonly concentrated in an SPMD. The U.S. Army Corp of Engineers Environmental Laboratory in Vicksburg, Miss., ran a P450RGS assay on each SPMD extract to measure enzyme induction in the presence of hydrocarbons (Murk and others, 1996). The P450RGS assay involves the production of a detoxifying enzyme encoded by the CYP1A1 gene in the presence of aryl hydrocarbon receptor type compounds that include polychlorinated biphenyls (PCBs), PAHs, polychlorinated dibenzo-p-dioxins (PCDDs), and polychlorinated dibenzofurans (PCDFs). The concentration of aryl hydrocarbon receptor compounds is expressed as the amount of dioxin, in toxic equivalents, that would induce the same response.

A complete listing of the chemical constituents analyzed for in the SPMD extract is in Sprague and others (2006). Analytical data from the SPMD extracts are in Bryant and others (2007).

For quality control, a set of SPMD field blanks was exposed during deployment and recovery to account for atmospheric contamination. In addition, laboratory dialysis of field blanks and analysis of solvent blanks were done. Seven organic compounds were detected in the dialysis and field blank analyses. Of these, two phthalates and isoquinoline were detected in all dialysis and field blanks, indicating the common occurrence of these compounds in the environment. Phthalates are commonly used plasticizers and are ubiquitous in the environment (Thuren, 1986). The two phthalates, diethylhexyl phthalate and diethyl phthalate, were the only compounds detected in the blanks that also were detected in the environmental samples. However, phthalate concentrations in the blanks were within the range of phthalate concentrations for all environmental samples. Therefore, no adjustments were made to the concentration of either phthalate compound in any of the environmental samples.

Three duplicate SPMDs were installed at randomly selected sites in the study area. Constituent concentrations in duplicate samples greater than the laboratory reporting level differed by no more than 30 percent from constituent concentrations in primary samples. No adjustments were made to reported concentrations on the basis of the difference between the primary and duplicate sample concentrations.

Laboratory spike samples for constituent concentrations measured by gas chromatograph (GC) and mass spectrometry (MS) were analyzed. Percentage recoveries from GC/MS analysis of SPMD extracts from spike samples ranged from 82 percent for decafluorobiphenyl to 130 percent for $p, p$ '-DDT-d8. The range in percentage recoveries was within 
the range of 80 to 136 percent recovery from GC/MS analysis of all SPMD extracts from the USGS NAWQA national effects of urbanization on stream ecosystems dataset (Bryant and others, 2007). No corrections to data were made on the basis of the results from spike recoveries.

\section{Physical Characteristics}

Streamflow and water temperature were monitored continuously. Basin-, segment-, and reach-scale habitat assessments were made. A complete listing of the basin-, segment-, and reach-scale physical habitat variables is in Sprague and others (2006).

\section{Streamflow}

A pressure transducer (Stevens Water Monitoring System, Model PS310) with an internal datalogger was installed at each site to record stage over the period of study. Each site was instrumented with a pressure transducer for a period of 8 months prior to biological and stream habitat sampling. The pressure transducers measured stage at 20-minute intervals over a range of 0 to 30 meters. The pressure transducers installed were non-vented units requiring corrections for fluctuations in barometric pressure by using atmospheric barometric pressure data recorded hourly at Dallas-Fort Worth International Airport. Each stage reading was corrected by comparing the difference between barometric pressure recorded when the pressure transducer was zeroed to the barometric pressure at the time of each reading. The difference was converted to an equivalent water depth and applied to the uncorrected stage reading to obtain a corrected stage reading.

Stage data from the Model PS310 do not have the precision of \pm 0.003 meter as required by the USGS (Sauer, 2002). However, the intended use of the pressure transducers for this study was to provide a measure of change in stage over the gradient of urban intensity to calculate a number of hydrologic metrics. Therefore, the precision of the Model PS310 was judged sufficient for the needs of the study.

Continuous discharge data could not be accurately developed within the 8-month period that the pressure transducers were deployed. Because of the limitations in using stage data to calculate flow metrics, stage was converted to crosssectional area to acquire a continuous flow-area dataset. This was accomplished by surveying a cross section of the channel at each site where a pressure transducer was deployed and determining a cross-sectional area for each stage measurement recorded. A stage to cross-sectional area rating was determined for each instrumented site, and this rating was used to convert the continuous stage data to continuous flow-area data.

An 8-month period of record was used to provide hydrologic data that would reflect seasonal differences in rainfall, base flow, and streamflow. An incomplete record of stage for many sites resulted from instrument failure or erroneous data that were deleted from the record. Records of stage at 13 of the original 28 sites over the 8-month period were complete enough to compute 57 variables from streamflow. Streamflowrelated variables, their definitions, and the data are in Giddings and others (2009).

\section{Temperature}

The Stevens Water Monitoring Systems Model PS310 pressure transducers used to record stream stage also were used to record water temperature during the period of transducer operation. Water temperature was recorded at 20-minute intervals at each site. The accuracy and precision of temperature readings from the Model PS310 were verified by comparing temperature readings from the PS310 to a National Institute of Standards and Technology thermometer in a water bath before field installation of the pressure transducers. Records of temperature at 13 of the original 28 sites over the 8-month period were complete enough to compute 57 variables from temperature. Temperature-related variables, their definitions, and the data are in Giddings and others (2009).

\section{Physical Habitat}

Basin-, segment-, and reach-scale habitat assessments were done for each site following established NAWQA procedures (Fitzpatrick and others, 1998). Basin-scale habitat assessments included drainage area, drainage density, drainage shape, drainage texture, basin length, basin relief, and cumulative stream length. Segment-level variables included channel gradient, channel slope, channel sinuosity, and segment length. A segment was defined as a length of channel bounded by a physical discontinuity such as a tributary confluence or point discharge that bounded the reach selected for study. Basin- and segment-scale measures for the variables listed above were obtained using GIS and topographic maps. Upstream and downstream reach boundaries were marked, and latitude and longitude recorded for each boundary marker using a handheld global positioning system (GPS). Eleven transects were established in each reach at equal intervals over the length of the reach. Physical habitat measurements made at each transect included stream depth, stream width, stream velocity, bed substrate, habitat cover, bank angle, canopy closure, and bank vegetation. Reach-scale habitat assessments were done concurrently with biological assessments to ensure that both datasets were collected during the same flow conditions. Ninety-three basin-, segment-, and reach-scale variables were computed. These variables, their definitions, and the data are in Giddings and others (2009).

\section{Biological Characteristics}

Biological sampling was done in June and early July 2004. All biological data collection was done in the selected reaches. All biological and reach-level habitat assessments were completed in each reach on the same day. All biological samples were reach-based composite 
samples collected according to established NAWQA protocols (Moulton and others, 2002). Biological response variables used for this report include species richness, diversity, relative abundance, and selected metrics as described for benthic macroinvertebrates in Cuffney and others (2005), for algae in Potapova and others (2005), and for fish in Meador and others (2005). Biological variables, their definitions, and biological data collected are in Giddings and others (2009).

\section{Fish}

The fish assemblage in each reach was sampled using electrofishing and seining sampling methods. Two passes of each reach were done using a Smith-Root ${ }^{\circledR}$ Model GP 5.1 barge electrofishing unit or a Smith-Root ${ }^{\circledR}$ Model LR-24 backpack unit depending on water depths in the reach. The barge electrofishing unit was the preferred unit because it allowed access to deeper areas; however, the backpack unit was used in a few reaches where the barge was unable to be floated effectively. An equal sampling effort using the electrofishing equipment was accomplished by standardizing each pass through a reach to a minimum of 900 seconds, setting the power output to 3 to 4 amps, and the pulse frequency to 60 hertz. Three discrete seine hauls were done in each reach to supplement electrofishing. The seine hauls were distributed across the dominant geomorphic channel unit in the reach with one seine haul completed in each geomorphic channel unit represented.

All fish collected in a reach were held in aerated holding tanks pending field processing. Each fish was identified in the field if possible. The first 30 fish of each species were identified to species, weighed to the nearest 0.1 gram, and checked for external anomalies such as lesions and parasites. Fish that could not be identified in the field were fixed in 10-percent buffered formalin and returned to the USGS Texas Water Science Center in Austin for sorting and identification. All retained fish were transferred to 70-percent ethanol as soon as possible after collection. Non-game species and problematic identifications were verified by ichthyologists with the Texas Natural History Collections at The University of Texas at Austin. All vouchered specimens were deposited with the ichthyology collections manager of the Texas Natural History Collections. Twenty-seven fish variables were computed. Fish variable definitions and the data collected are in Giddings and others (2009).

\section{Benthic Macroinvertebrates}

Two benthic macroinvertebrate samples were collected in each reach following methods described in Moulton and others (2002). A qualitative multi-habitat (QMH) sample was collected by compositing discrete samples collected from all the microhabitats represented in the reach. A 500-micrometer d-frame net was used to collect the QMH samples. A semiquantitative sample was obtained by collecting a sample from the richest targeted habitat (RTH) in each of five woody snags in flowing sections of the reach and compositing the five samples into a single sample. A 500-micrometermesh slack sampler was used to collect the semiquantitative samples by removing a piece of submerged wood with a diameter of at least 2 centimeters and a length of at least 15 centimeters from each woody snag sampled. Organisms on the piece of wood were dislodged by gently brushing and washing the organisms into the net of the slack sampler.

All benthic macroinvertebrate composite samples were fixed with 10-percent buffered formalin and submitted to the USGS National Water Quality Laboratory for identification and enumeration following methods described in Moulton and others (2000). Definitions for the 145 benthic macroinvertebrate variables computed and the data are in Giddings and others (2009).

\section{Algae}

Two quantitative periphytic algae samples were collected in each reach according to methods described in Moulton and others (2002). One was an RTH algae sample collected by gently brushing the attached algae from five pieces of woody debris collected in flow sections of the reach using methods similar to those used for the RTH benthic macroinvertebrate sample. The five RTH algae samples were composited and homogenized before sample splitting and filtering. A second algae sample was collected from five depositional areas in the stream margin where fine sediment such as silt and clay typically accumulates. These samples were referred to as depositional target habitat (DTH) algae samples; they were collected by placing a 47-millimeter petri dish into the streambed, placing a spatula under the petri dish, and removing the petri dish from the streambed. The five DTH algae samples collected in each reach were composited to form a single sample.

Aliquots from the composited RTH and DTH algae samples were filtered onsite through a 45-micrometer glass-fiber filter to remove algae from the composited sample. The filters were wrapped in foil, sealed, packed on dry ice, and submitted to the USGS National Water Quality Laboratory for the analysis of chlorophyll- $a$ (Arar and Collins, 1997) and ash-free dry mass (Britton and Greeson, 1987). A separate aliquot was retained, placed in a high-density polyethylene jar, and preserved with 10-percent buffered formalin for taxa identification and enumeration. Samples for taxa identification and enumeration were submitted to the Academy of Natural Sciences in Philadelphia, Pa., and processed using protocols described by Charles and others (2002). Definitions of the 79 algae variables computed for RTH and DTH algae samples and the data are in Giddings and others (2009).

\section{Data Analysis}

The principal objective of data analysis for this report was to determine whether the chemical, physical, or biological 
variables or metrics measured related to the gradient of urbanization as defined by the UIIs sorted from smallest to largest. In addition, for those variables or metrics that indicated a statistically significant relation with the gradient of urbanization, a threshold analysis was done to determine whether the response was linear or nonlinear. All data analysis was done using STATISTICA version 7.0 (StatSoft, Inc., 2006).

Spearman's rho correlation was used to evaluate the relations between the various chemical, physical, and biological variables and the UII. Spearman's rho was used because of the expected nonlinear relation between many of the chemical, physical, and biological variables and the UII. Spearman's rho correlation uses ranked data and measures the monotonic association between variables, thus making it suitable for nonlinear relations. Variables for which absolute values of rho were greater than or equal to .50 and were significant at the .05 level (p-value less than .05) were retained for further analysis.

Chemical, physical, and biological variables correlated with the UII were retained for threshold analysis to indicate any pattern of response to the UII. Locally weighted scatterplot smoothing (LOWESS) (with smoothing factor 0.5) was used to indicate the presence of a threshold response. A threshold in the context of LOWESS is defined here as the minimum UII score that resulted in a notable change in the slope of the smooth line (notable change in the linear response) of a chemical, physical, or biological variable relative to the UII. A visual inspection of each scatterplot smooth line was done to indicate any thresholds. If no threshold was observed, linear regression was used to obtain the slope of the relation over the range of the UII. If a threshold was observed, the response variable and the associated UII data less than and greater than the threshold UII were grouped into separate datasets. Tests for normality were done on these datasets and appropriate transformations of non-normally distributed data were made before parametric statistical analysis to indicate whether a threshold response was significant. An analysis of covariance (ANCOVA) of the homogeneity of slopes for the datasets was done to test whether a threshold response was significant. An F-test indicated whether the pre- and postthreshold slopes were significantly different from one another. A p-value less than or equal to .1 rather than .05 for the F-statistic was considered indicative of a significant threshold response because of the relatively small number of sites (small sample size) above and below the threshold value. The ability of a statistical test to detect a significant difference generally decreases as the sample size decreases (Park, 2004).

After threshold analysis yielded the chemical, physical, and biological variables that showed significant threshold responses to the UII, linear regression between the UII and selected land-use/land-cover, infrastructure, and socioeconomic variables was used to estimate the value of each landuse/land-cover, infrastructure, and socioeconomic variable for the corresponding UII score at the observed threshold. The land-use/land-cover, infrastructure, and socioeconomic variables selected were those that were most strongly correlated with the UII based on Spearman's rho tests (absolute value of rho equal to or greater than .90). Each selected land-use/ land-cover, infrastructure, and socioeconomic variable was regressed on the UII, yielding a regression equation for each. Then the value of each of land-use/land-cover, infrastructure, and socioeconomic variable for the threshold value of each chemical, physical, and biological variable that showed a significant threshold response to the UII was estimated from the respective regression equation.

\section{Effects of Urbanization on Stream Characteristics}

\section{Response of Chemical Characteristics to Gradient of Urban Intensity}

Ninety-four water-chemistry characteristics (variables) and one measure of potential toxicity from a bioassay (a variable categorized with chemical characteristics for convenience) were compared to the UII using Spearman's rho correlation. Of these comparisons, the concentrations of two pesticides and one measure of potential toxicity from compounds sequestered in SPMDs were significantly positively correlated with the UII (table 3 ). The strongest positive correlation (rho equals .764) was for the insecticide diazinon, and the other significant positive correlation (rho equals .607) was for the herbicide simazine. Potential toxicity as measured by the P450RGS assay in 2,3,7,8-Tetrachlorodibenzo- $p$ dioxin (TCDD) toxicity equivalents from SPMD extracts was significantly positively correlated (rho equals .521) to the UII.

No threshold responses to the UII for diazinon and simazine concentrations were observed over the entire range of UII scores. The linear correlation for diazinon with the UII was significant (p-value less than .001; table 4), but the linear correlation for simazine with the UII was not (p-value equals .547). The P450RGS assay indicated a threshold response to the UII at a UII of about 50 (fig. 5; table 4); however, regression of TCDD on the UII (fig. 6) and a test of the homogeneity of regression slopes for the pre- and post-threshold relations indicated that the threshold was not significant at the .1 level (p-value equals .1275; table 4). No statistically significant relations between the UII and concentrations of suspended sediment, total nitrogen, or total phosphorous, or any of the major ions were indicated.

\section{Response of Physical Characteristics to Gradient of Urban Intensity}

Eleven of 59 physical characteristics (variables) from streamflow were significantly correlated with the UII (table 3). Temperature was not significantly correlated with the UII, and none of the physical habitat measurements were significantly correlated with the UII. 


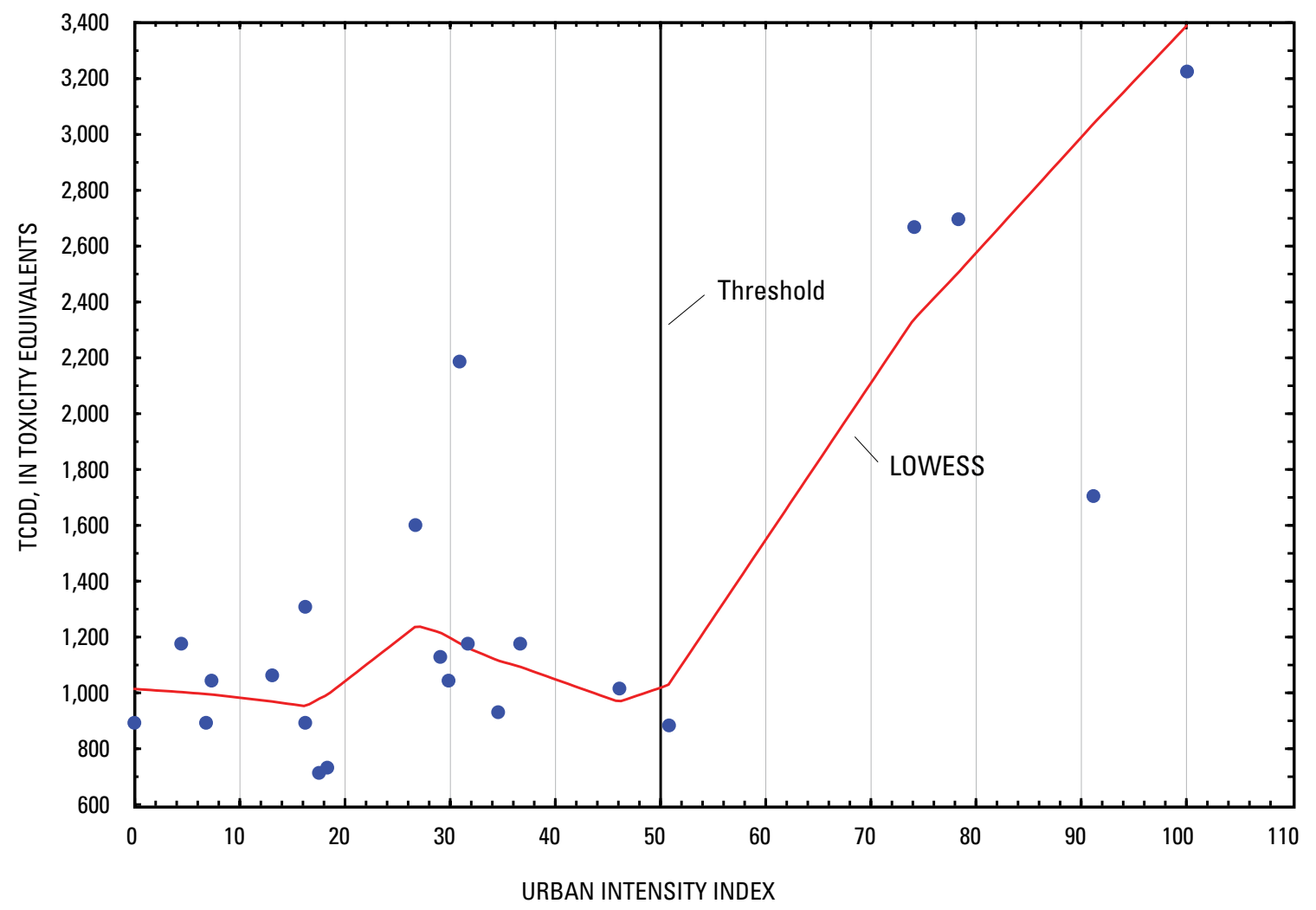

Figure 5. Potential toxicity, as measured in toxic equivalents of 2,3,7,8-Tetrachloro- $p$-dioxin (TCDD) from semipermeable membrane device extracts, relative to urban intensity index with locally weighted scatterplot smoothing (LOWESS) smooth for sites in and near the Dallas-Fort Worth metropolitan area, Texas.

Seven physical variables categorized as streamflow flashiness metrics were significantly positively correlated with the UII (table 3). The variable Day_pctchange, which is the absolute value of the relative change in daily mean crosssectional area, was significantly positively correlated (rho equals .617) to the UII, but the variable did not show a threshold response to the UII. However, Day_pctchange did have a significant linear response (p-value equals .027) to the UII (table 4). The relative change in daily mean cross-sectional area over the period of record used for this report might not be sensitive enough to the UII for this metric to have a threshold response. The other six flashiness metrics significantly positively correlated with the UII are measures of the frequency of rising or falling events over an hourly change in absolute cross-sectional area that is greater than some multiple of the median rise or fall. If Periodr9, which is the hourly change in cross-sectional area that is greater than nine times the median rise over the period of record, is significantly correlated with the UII, then Periodr5 (substitute five times median) and Periodr7 (substitute seven times median) also will be significantly correlated with the UII; and similarly for the metrics associated with falling events (Periodf9, Periodf7, and Periodf5). Periodr9 did not show a threshold response to the UII because of the large variability in Periodr9 values between a UII of 10 and 30 that moderated any definitive threshold. Periodr9 did have a significant linear response (p-value less than .01) to the UII (table 4). Several sites had as many as 30 Periodr9 events compared to as few as four to 10 Periodr9 events for sites with smaller UII scores. None of the five other metrics associated with rising or falling events showed a threshold response or significant linear response to the UII.

A number of physical variables are metrics that evaluate the duration of high and low pulses over a period of record. For this report, the duration of a high pulse is defined as the period of time that streamflow is greater than at least the 75th percentile of streamflow over the period of record. A low pulse is defined as the period of time that streamflow is less than at least the 25th percentile of streamflow over the period of record. Two high-pulse metrics, Mxh_95 and Mdh_95, were significantly negatively correlated with the UII (table 3 ). Mxh_95 is the maximum duration of a pulse for a site that is greater than the 95th percentile of streamflow for all sites for the period of record. No threshold response was observed for Mxh_95, but this metric did show a significant linear response (p-value equals .032) to the UII (table 4). The streamflow metric Mdh_95 is the median duration of a pulse for a site that is greater than the 95th percentile of streamflow for all sites for the period of record. Like the Mxh_95 metric, the Mdh_95 metric did not indicate a threshold response to the UII; however, Mdh_95 did have a significant linear response (p-value 


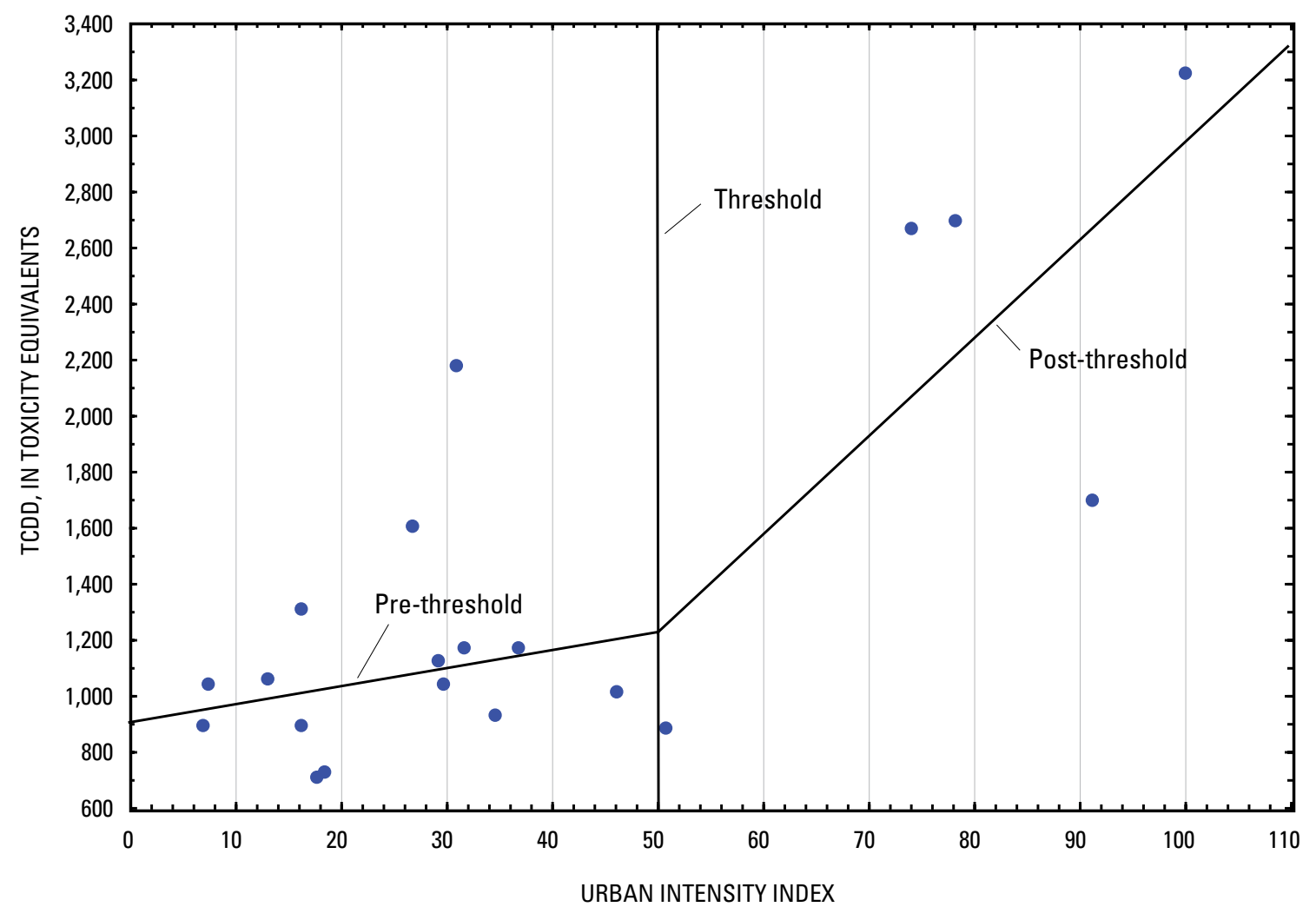

Figure 6. Potential toxicity, as measured in toxic equivalents of 2,3,7,8-Tetrachloro- $p$-dioxin (TCDD) from semipermeable membrane device extracts, relative to urban intensity index with pre- and post-threshold regression lines for sites in and near the Dallas-Fort Worth metropolitan area, Texas.

equals .021) to the UII (table 4). Two low-pulse metrics, Mxl_25 and Mxl_10, were significantly negatively correlated with the UII (table 3). The Mxl metric is the maximum duration of low-flow pulses that are less than the 25th percentile $\left(\mathrm{Mxl} \_25\right)$ or 10th percentile (Mxl_10) of streamflow for all sites over the period of record. Mxl_25 indicated a threshold response to the UII (figs. 7, 8) with a significant difference (p-value equals .0004) in the homogeneity of slopes for values above and below the observed threshold (table 4). The threshold response of the Mxl_25 occurred at a UII of about 32. The Mxl_10 metric did not show a threshold response or significant linear response to the UII.

\section{Response of Biological Characteristics to Gradient of Urban Intensity}

\section{Fish Response}

None of the fish metrics, which include a regional index of biotic integrity (IBI) for the Blackland Prairie (Linam and others, 2002), individual IBI metrics, number of fish collected, or fish species richness, were significantly correlated with the UII in the Blackland Prairie streams of this report.

\section{Benthic Macroinvertebrate Response}

Two QMH benthic macroinvertebrate metrics, predator richness and percentage filterer-collector richness, were significantly correlated with the UII (table 3 ). Predator richness was negatively correlated (rho equals -.667) with the UII, and percentage filterer-collector richness was positively correlated (rho equals .502) with the UII. No threshold response to the UII was observed for predator richness (table 5). Predator richness showed a significant negative linear response (p-value equals .003) to the UII. No threshold response to the UII was observed for percentage filterer-collector richness, but the metric showed a significant positive linear response (p-value equals .033) to the UII.

Three RTH benthic macroinvertebrate metrics, Margalef's richness, predator richness, and omnivore richness were significantly negatively correlated with the UII (table 3). Margalef's richness was the only RTH metric that indicated a threshold response to the UII (figs. 9, 10). The test of homogeneity of regression slopes for the pre- and post-threshold Margalef's richness relations indicated that the threshold was significant at the .1 level (p-value equals .057) (table 5). 
Table 3. Spearman's rho correlation coefficients significant at the .05 level for correlation between chemical, physical, and biological variables and urban intensity index for reaches and subbasins in and near the Dallas-Fort Worth metropolitan area, Texas.

[All rho values are significant at the .05 level; TCDD, 2,3,7,8,-Tetrachlorodibenzo-p-dioxin; QMH, qualitative multi-habitat; RTH, richest targeted habitat; DTH, depositional targeted habitat]

\begin{tabular}{|c|c|}
\hline Variable type and variables & rho \\
\hline \multicolumn{2}{|l|}{ Chemical } \\
\hline \multicolumn{2}{|l|}{ Pesticides } \\
\hline Diazinon concentration & .764 \\
\hline Simazine concentration & .607 \\
\hline \multicolumn{2}{|l|}{ Potential toxicity bioassay } \\
\hline TCDD toxicity equivalents & .521 \\
\hline
\end{tabular}

Physical' (from streamflow)

Flashiness metrics

Day_pctchange (absolute value of the relative change in daily mean cross-sectional area ${ }^{2}$ ) .617

Periodr5 (hourly change in cross-sectional area ${ }^{2}$ that is greater than five times the median rise over the period of record) .714

Periodr7 (hourly change in cross-sectional area ${ }^{2}$ that is greater than seven times the median rise over the period of record) .717

Periodr9 (hourly change in cross-sectional area ${ }^{2}$ that is greater than nine times the median rise over the period of record) .821

Periodf5 (hourly change in cross-sectional area ${ }^{2}$ that is greater than five times the median fall over the period of record) .718

Periodf7 (hourly change in cross-sectional area $^{2}$ that is greater than seven times the median fall over the period of record) .766

Periodf9 (hourly change in cross-sectional area ${ }^{2}$ that is greater than nine times the median fall over the period of record) .729

Duration of high-pulse metrics

Mxh_95 (maximum duration of a pulse for a site that is greater than the 95th percentile of streamflow for all sites for the period of record)

Mdh_95 (median duration of a pulse for a site that is greater than the 95th percentile of streamflow for all sites for the period of record)

Duration of low-pulse metrics

Mxl_25 (maximum duration of low-flow pulses that are less than the 25th percentile of streamflow for all sites over the $\quad-602$ period of record)

Mxl_10 (maximum duration of low-flow pulses that are less than the 10th percentile of streamflow for all sites over the period of record)

\section{Biological}

Benthic macroinvertebrates (QMH)

Predator richness (number of unique taxa)

Percentage filterer-collector richness (number of unique taxa)

Benthic macroinvertebrates (RTH)

Margalef's richness (number of unique taxa)

$-.624$

Predator richness (number of unique taxa)

$-.504$

Omnivore richness (number of unique taxa)

Periphytic algae - classified taxa - diatoms only (RTH)

SP_AP_BP (moderate oxidation)

ON_AH_BP (nitrogen autotrophic - high inorganic nitrogen)

ON_HF_BP (nitrogen heterotrophic - facultative)

ON_NH_BP (nitrogen heterotrophic)

PH_CN_BP (pH circumneutral)

OT_VL_DP (oxygen tolerance index)

Periphytic algae - classified taxa - diatoms only (DTH)

ON_HF_DP (nitrogen heterotrophic - facultative)

ON_AL_DP (nitrogen autotrophic - low organic nitrogen)

ON_NH_DP (nitrogen heterotrophic)

TR_OM_DP (oligomesotrophic)

${ }^{1}$ Variable definitions from Giddings and others (2009).

${ }^{2}$ Cross-sectional area used in this report because continuous discharge data could not be accurately developed during data-collection period. 
Table 4. Statistics associated with chemical and physical variables that showed a significant linear response or a threshold response to the urban intensity index for reaches and subbasins in and near the Dallas-Fort Worth metropolitan area, Texas.

[See table 3 for definitions of physical variables; UII, urban intensity index; r, correlation coefficient; s, slope of regression line; p, p-value; F, F-statistic; <, less than; --, not applicable; TCDD,2,3,7,8-Tetrachlorodibenzo- $p$-dioxin]

\begin{tabular}{|c|c|c|c|c|c|c|c|c|}
\hline \multirow{2}{*}{ Variable } & \multicolumn{3}{|c|}{$\begin{array}{l}\text { Variable with no } \\
\text { observed threshold } \\
\text { response to UII }\end{array}$} & \multicolumn{5}{|c|}{$\begin{array}{l}\text { Variable with observed } \\
\text { threshold response to UII }\end{array}$} \\
\hline & $\mathbf{r}$ & $\mathbf{s}$ & $\mathbf{p}$ & $\begin{array}{l}\text { Threshold } \\
\text { UII }\end{array}$ & $\begin{array}{l}\text { Pre- } \\
\text { threshold } \\
\text { s }\end{array}$ & $\begin{array}{l}\text { Post- } \\
\text { threshold } \\
\text { s }\end{array}$ & $\mathbf{F}$ & $\mathbf{p}$ \\
\hline \multicolumn{9}{|c|}{ Chemical } \\
\hline Diazinon & .584 & .0002 & $<.001$ & -- & -- & -- & -- & -- \\
\hline Simazine & .015 & .0021 & .547 & -- & -- & -- & -- & -- \\
\hline TCDD & -- & -- & -- & 50 & 8.749 & 35.36 & 2.583 & .1275 \\
\hline \multicolumn{9}{|c|}{ Physical (from streamflow) } \\
\hline Day_pctchange & .323 & .182 & .027 & -- & -- & -- & -- & -- \\
\hline Periodr9 & .626 & .665 & $<.01$ & -- & -- & -- & -- & -- \\
\hline Mxh_95 & .244 & -.354 & .032 & -- & -- & -- & -- & -- \\
\hline Mdh_95 & .276 & .201 & .021 & -- & -- & -- & -- & -- \\
\hline Mxl_25 & -- & -- & -- & 32 & -46.94 & .661 & 24.459 & .0004 \\
\hline
\end{tabular}

\section{Periphytic Algae Response}

The majority of unique taxa collected in the periphytic algae samples were diatoms. Six RTH periphytic algae metrics were correlated with the UII (table 3). Several RTH metrics correlated with the UII are indicators of either low inorganic or high organic nitrogen concentrations. One negatively correlated RTH metric, ON_AH_BP, indicated the presence of nitrogen autotrophic algae and typically is related to high concentrations of inorganic nitrogen. Two positively correlated RTH metrics, ON_HF_BP and ON_NH_BP, indicate the presence of nitrogen heterotrophic algae that respond to organic nitrogen concentrations. The positively correlated RTH metric PH_CN_BP indicates the presence of periphytic algae that are not $\mathrm{pH}$ selective or what is often termed $\mathrm{pH}$ circumneutral. The positively correlated RTH metric OT_VL_DP indicates the presence of algae that are tolerant of low dissolved oxygen conditions. Of the six RTH periphytic algae metrics, five showed no notable threshold response to the UII (table 6); but all five showed significant linear responses to the UII ( $p$-values less than .001 to .022). Only the metric OT_VL_DP showed a threshold response at a UII of about 48 (figs. 11, 12). The threshold was significant on the basis of the homogeneity of slopes test (p-value less than .001).

Six DTH periphytic algae metrics were correlated with the UII (table 3). Only the nitrogen autotrophic metric ON_AL_DP, which indicates low organic nitrogen concentrations, was negatively correlated with the UII; the other five were positively correlated. Of the six metrics, five showed no threshold response to the UII (table 6); three of the five showed significant linear responses to the UII (p-values less than .001 to .021), one showed a borderline significant response (p-value equals .054), and one showed no significant response (p-value equals .239). Only the nitrogen heterotrophic metric ON_NH_DP, which indicates the presence of algal taxa tolerant to elevated concentrations of organically bound nitrogen, showed a threshold response at a UII of about 46 (figs. 13, 14). The threshold was significant based on the homogeneity of slopes test (p-value equals .029).

\section{Estimated Threshold Values for Selected Land-Use/Land-Cover, Infrastructure, and Socioeconomic Variables}

The land-use/land-cover, infrastructure, and socioeconomic variables that were most strongly correlated with the UII based on Spearman's rho tests are percentage developed, mean percentage impervious surface, road density, and density of housing units (table 7). Each of these variables was regressed on the UII, yielding a regression equation for each. The value of each land-use/land-cover, infrastructure, and socioeconomic variable for the threshold value of each physical and biological variable that showed a significant threshold response to the UII was estimated from the respective regression equation.

The magnitudes of the estimated threshold values of all four land-use/land-cover, infrastructure, and socioeconomic variables for each of the four physical and biological variables (table 7) ranked the same as the threshold values of the UII for 


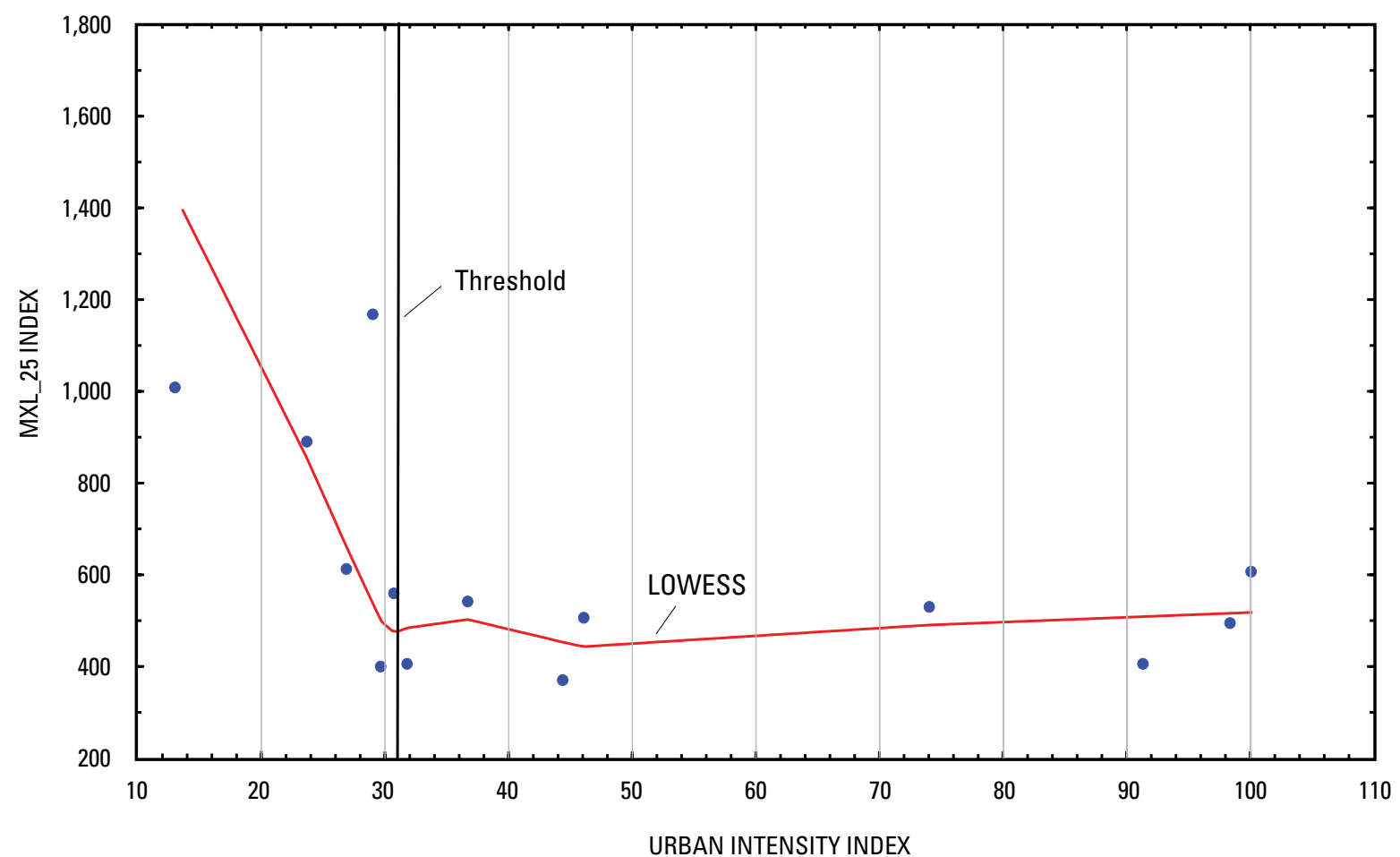

Figure 7. The metric (index) Mxl_25 (maximum duration of low-flow pulses less than the 25th percentile of streamflow) relative to urban intensity index with locally weighted scatterplot smoothing (LOWESS) smooth for sites in and near the Dallas-Fort Worth metropolitan area, Texas.

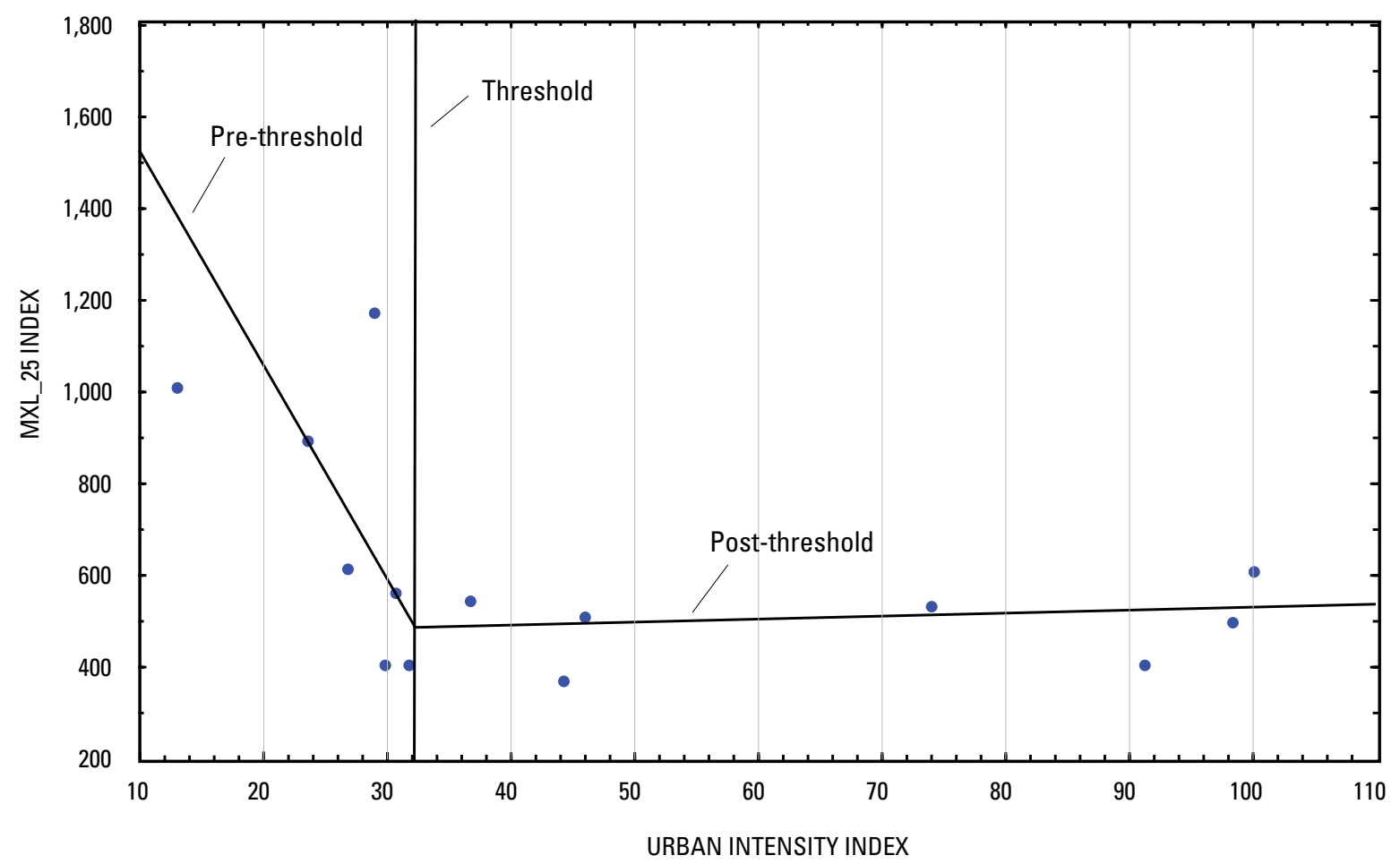

Figure 8. The metric (index) Mxl_25 (maximum duration of low-flow pulses less than the 25th percentile of streamflow) relative to urban intensity index with pre- and post-threshold regression lines for sites in and near the Dallas-Fort Worth metropolitan area, Texas. 


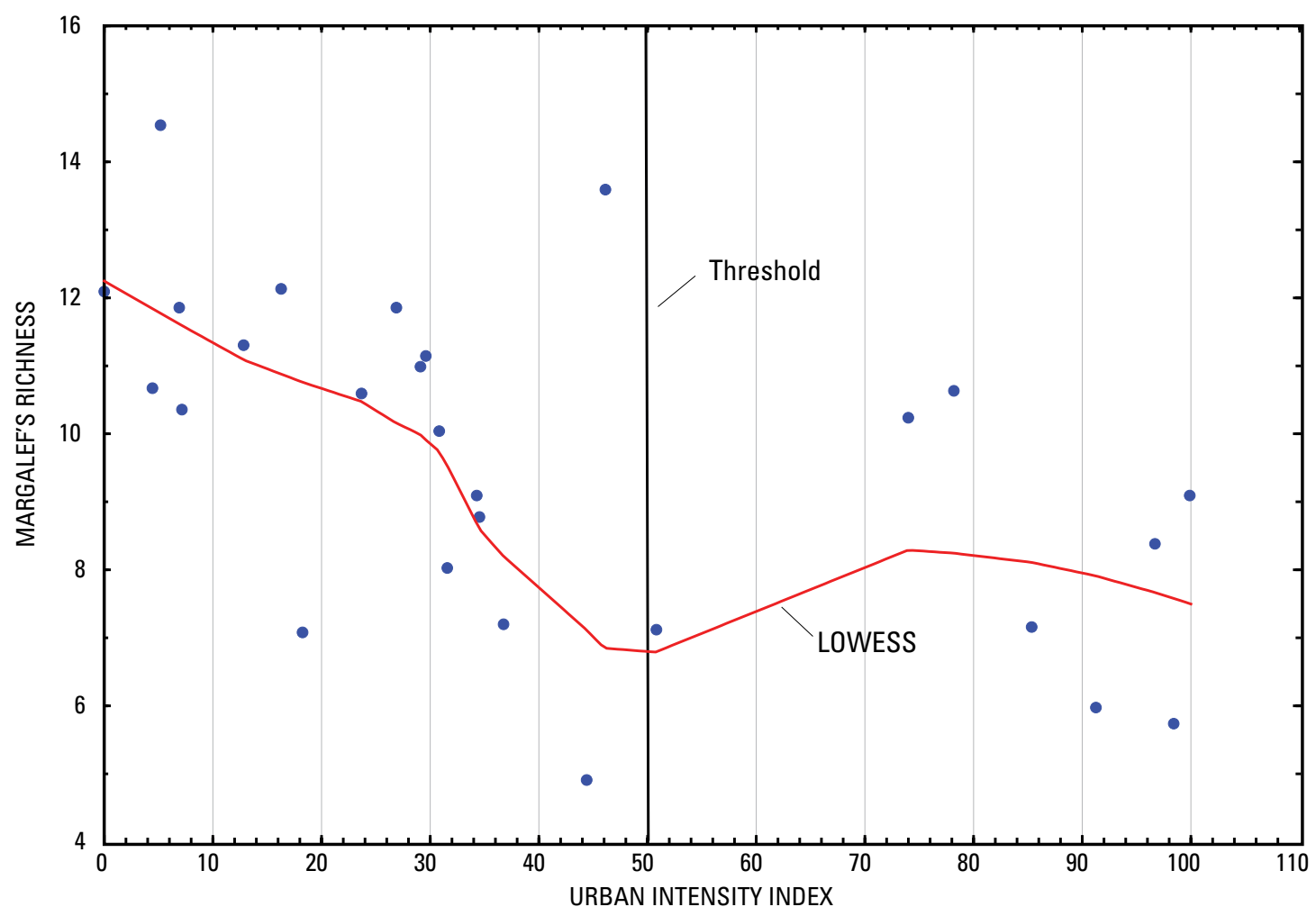

Figure 9. The benthic macroinvertebrate metric Margalef's richness relative to urban intensity index with locally weighted scatterplot smoothing (LOWESS) smooth for sites in and near the Dallas-Fort Worth metropolitan area, Texas.

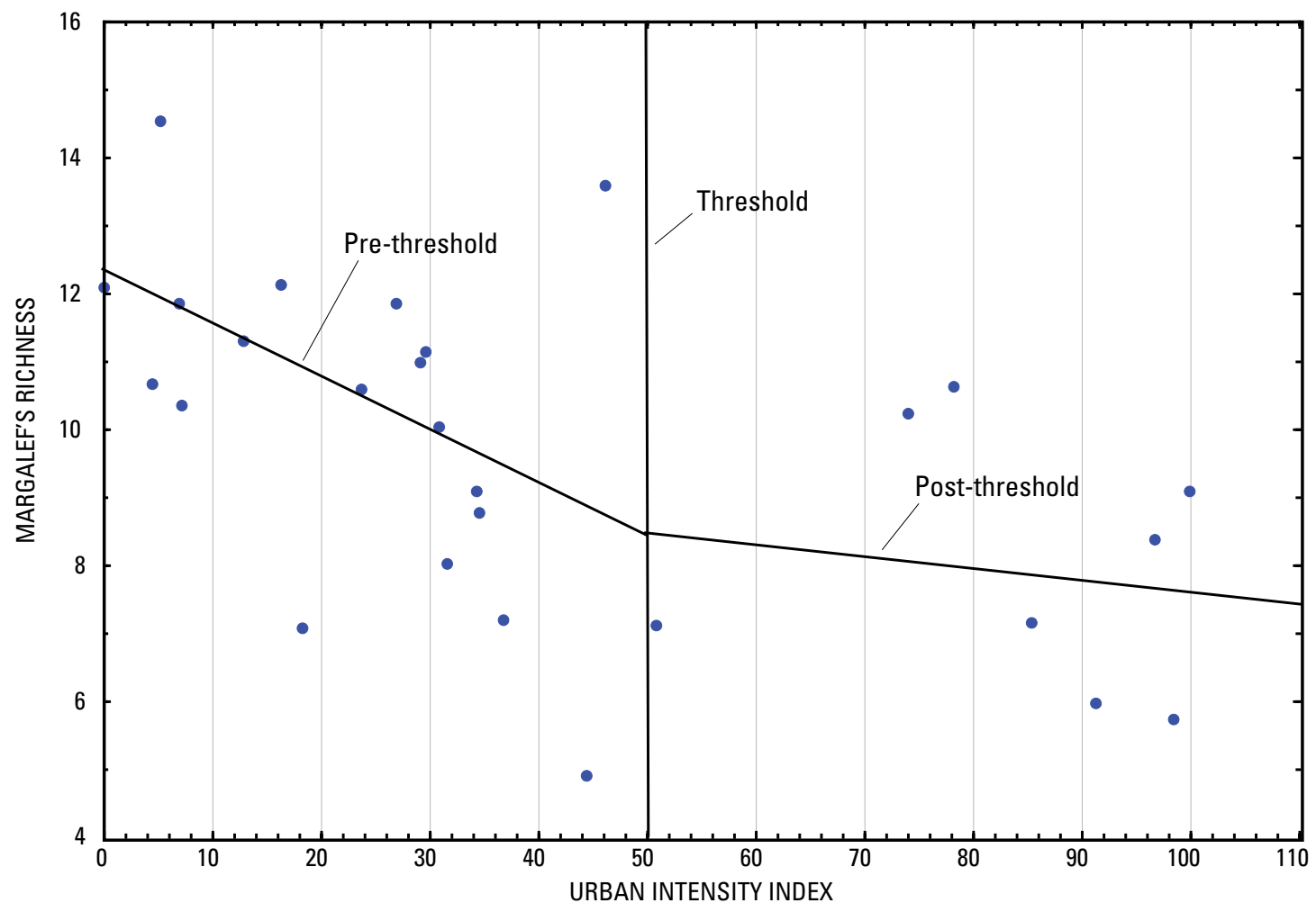

Figure 10. The benthic macroinvertebrate metric Margalef's richness relative to urban intensity index with pre- and post-threshold regression lines for sites in and near the Dallas-Fort Worth metropolitan area, Texas. 
Table 5. Statistics associated with biological variables (qualitative multi-habitat and richest targeted habitat benthic macroinvertebrate variables) that showed a significant linear response or a threshold response to the urban intensity index for reaches and subbasins in and near the Dallas-Fort Worth metropolitan area, Texas.

[See table 3 for definitions of variables; UII, urban intensity index; r, correlation coefficient; s, slope of regression line; p, p-value; F, F-statistic; QMH, qualitative multi-habitat; --, not applicable; RTH, richest targeted habitat; <, less than]

\begin{tabular}{|c|c|c|c|c|c|c|c|c|}
\hline \multirow[b]{2}{*}{ Variable } & \multicolumn{3}{|c|}{$\begin{array}{l}\text { Variable with no observed } \\
\text { threshold response to UII }\end{array}$} & \multicolumn{5}{|c|}{$\begin{array}{l}\text { Variable with observed threshold } \\
\text { response to UII }\end{array}$} \\
\hline & $\mathbf{r}$ & $\mathbf{s}$ & $\mathbf{p}$ & $\begin{array}{l}\text { Threshold } \\
\text { UII }\end{array}$ & $\begin{array}{c}\text { Pre- } \\
\text { threshold } \\
\text { s }\end{array}$ & $\begin{array}{l}\text { Post- } \\
\text { threshold } \\
\text { s }\end{array}$ & $\mathbf{F}$ & $\mathbf{p}$ \\
\hline Predator richness $(\mathrm{QMH})$ & .309 & -.073 & .003 & -- & -- & -- & -- & -- \\
\hline Percentage filterer-collector richness $(\mathrm{QMH})$ & .169 & .069 & .033 & -- & -- & -- & -- & -- \\
\hline Predator richness $(\mathrm{RTH})$ & .219 & -.056 & .014 & -- & -- & -- & -- & -- \\
\hline Omnivore richness (RTH) & .269 & -.016 & $<.01$ & -- & -- & -- & -- & -- \\
\hline
\end{tabular}

the physical and biological variables - from lowest to highest, Mxl_25, ON_NH_DP, OT_VL_DP, and Margalef's richness. Margalef's richness was the only metric that responded negatively to the UII for both the pre- and post-threshold ranges of the UII. The estimated threshold values for mean percentage impervious surface for each of the physical and biological variables were all less than 15 percent. The estimated threshold of 14.5 percent mean impervious surface that indicates a threshold response for Margalef's richness is consistent with observed thresholds for invertebrate assemblages in response to 5- to 18-percent mean impervious surface (Cuffney and others, 2005).

\section{Implications of Responses to Gradient of Urban Intensity}

Subbasins with UII scores between about 50 and 75 were lacking in this study. This gap could be an artifact of the criteria for the selected subbasins (for example, basin size and reach homogeneity). However, the gap might be partly the result of the pattern of urbanization in the DFW area that appears to be characterized by a dense urban and suburban core that transitions to a less developed rural landscape over a relatively short distance. The urban/rural transition is more abrupt than gradual, commonly occurring at beltways and highway loops that surround urban areas.

\section{Chemical Characteristics}

Diazinon has been the most widely used pesticide on lawns in the United States and was the most frequently detected insecticide in streams in the Trinity River Basin sampled as a part of the USGS NAWQA Program in the mid- 1990s (Land and others, 1998). Diazinon was detected in all urban stream samples. Simazine was detected in more than one-half the samples from agricultural and urban streams. The lack of a threshold response to the UII for both these pesticides might indicate the widespread use of these pesticides across a range of rural and urban settings in the DFW area.

The P450RGS assay indicates the presence of enzymeinducing planar organic compounds such as PAHs, PCBs, and PCDDs/PCDFs. The P450RGS assay measures the level of toxic equivalents that is related to cytochrome P1A1 (CYP1A1) enzyme induction caused by the presence of one or more of these compounds in the SPMD extracts. Thus the results might indicate the presence of potentially toxic compounds in the streams from which SPMD samples were collected (Anderson and others, 1995). The finding that potential toxicity as indicated by P450RGS assay is significantly positively correlated with the UII is consistent with that from a similar study in the Denver, Colo., urban area (Sprague and others, 2006) and indicates that potential toxicity from compounds such as PAHs, PCBs, and PCDDs/PCDFs increased with urbanization in the DFW subbasins.

Much of the Blackland Prairie is in cultivation, and the lack of a significant response of suspended sediment concentration to the UII might be the result of relatively large, long-term sources of sediment associated with recent and historical agricultural activities in the subbasins. However, the percentage of agricultural land use in the subbasins was not significantly correlated with the concentration of suspended sediment. Total nitrogen and total phosphorus concentrations also were not significantly correlated with the UII, a result that also might be related to agricultural activities. That is, if agricultural intensity in the subbasins over the years has remained relatively stable, the concentrations of suspended sediment and nutrients to subbasin streams resulting from agricultural activities would reflect that stability. And the influence of 


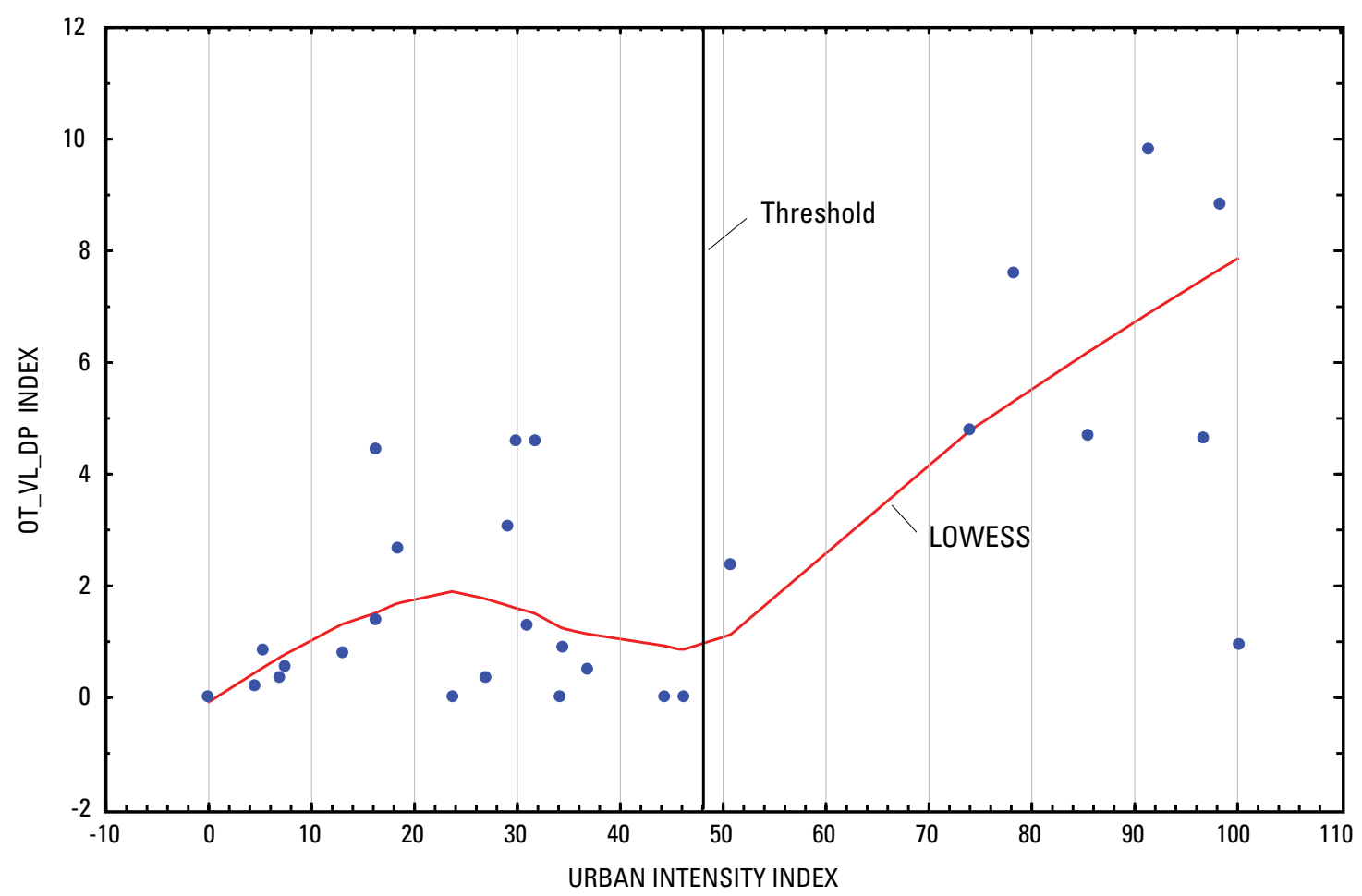

Figure 11. The periphytic algae metric (index) $0 T$ VL_DP, an index of tolerance to low dissolved oxygen, relative to urban intensity index with locally weighted scatterplot smoothing (LOWESS) smooth for sites in and near the Dallas-Fort Worth metropolitan area, Texas.

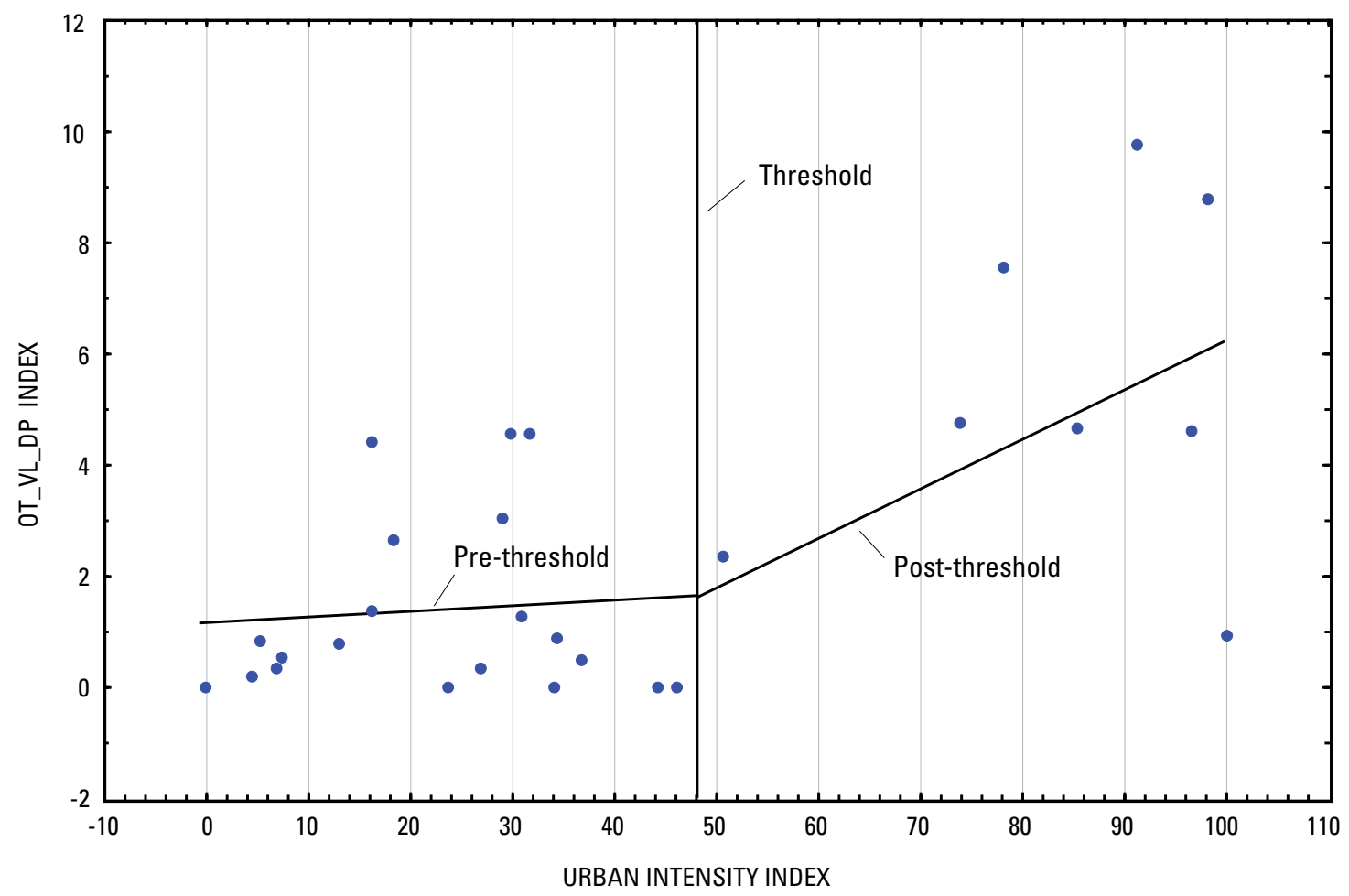

Figure 12. The periphytic algae metric (index) $0 T$ TL_DP, an index of tolerance to low dissolved oxygen, relative to urban intensity index with pre- and post-threshold regression lines for sites in and near the Dallas-Fort Worth metropolitan area, Texas. 


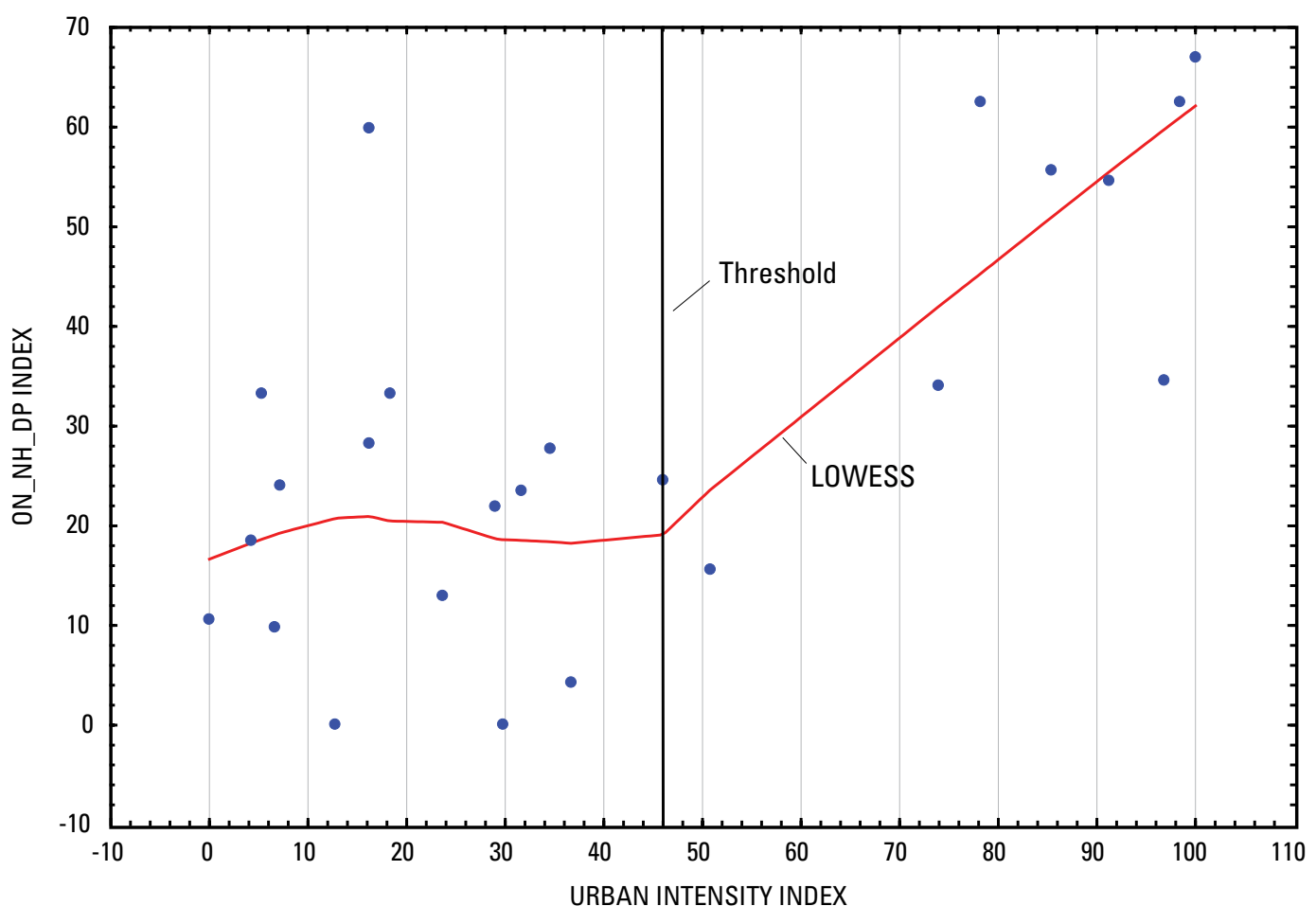

Figure 13. The periphytic algae metric (index) $0 N \_N H \_D P$, an index of the presence of nitrogen heterotrophic algae that respond to organic nitrogen concentrations, relative to urban intensity index with locally weighted scatterplot smoothing (LOWESS) smooth for sites in and near the Dallas-Fort Worth metropolitan area, Texas.

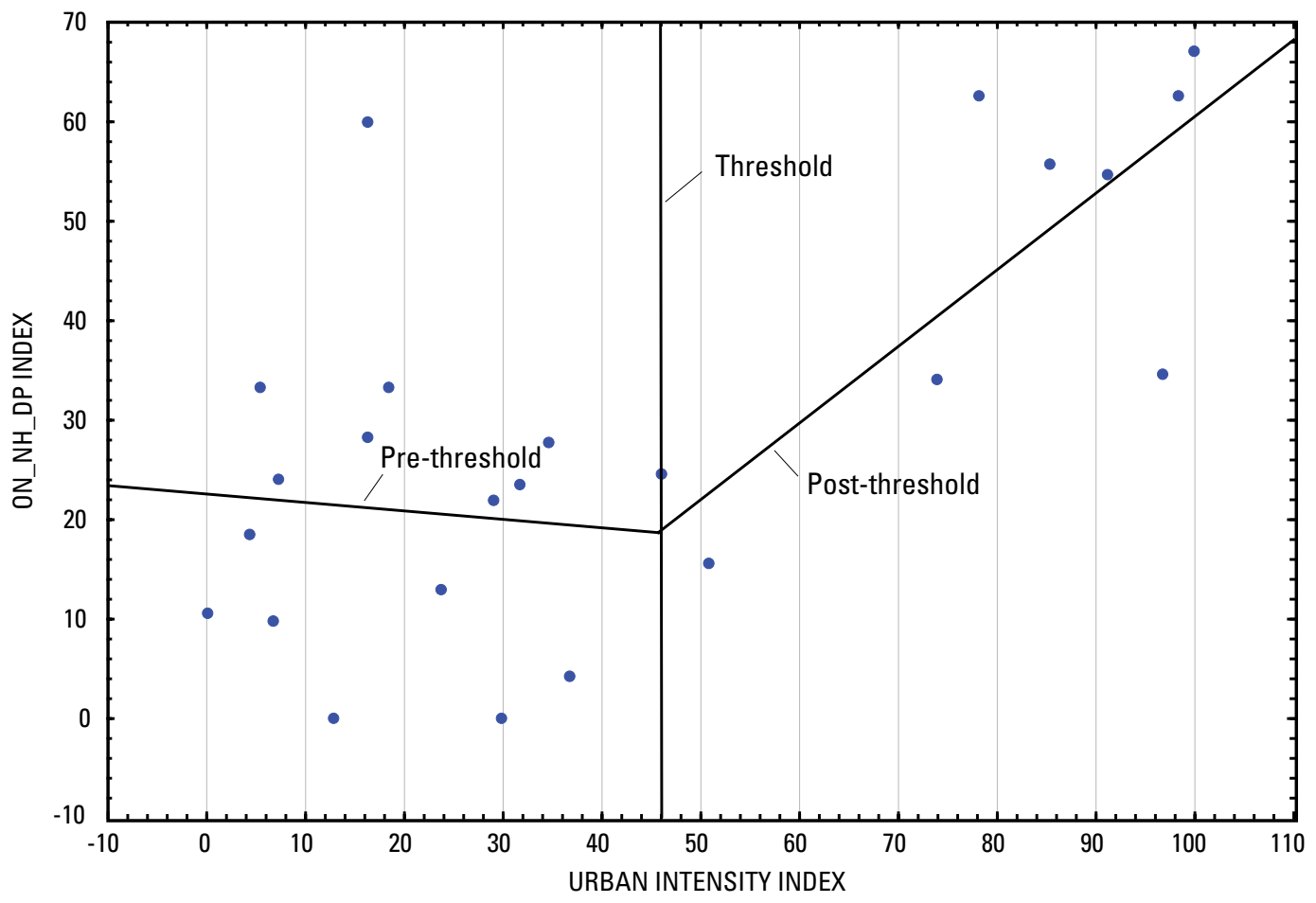

Figure 14. The periphytic algae metric (index) $0 N \_N H \_D P$, an index of the presence of nitrogen heterotrophic algae that respond to organic nitrogen concentrations, relative to urban intensity index with pre- and post-threshold regression lines for sites in and near the Dallas-Fort Worth metropolitan area, Texas. 
Table 6. Statistics associated with periphytic algae variables that showed a significant linear response or a threshold response to the urban intensity index for reaches and subbasins in and near the Dallas-Fort Worth metropolitan area, Texas.

[See table 3 for definitions of variables; DTH, depositional target habitat; RTH, richest targeted habitat; UII, urban intensity index; r, correlation coefficient; s, slope of regression line; p, p-value; F, F-statistic; --, not applicable; <, less than]

\begin{tabular}{|c|c|c|c|c|c|c|c|c|c|c|}
\hline \multirow{2}{*}{ Variable } & \multirow{2}{*}{$\begin{array}{c}\text { RTH } \\
\text { or } \\
\text { DTH } \\
\text { sample }\end{array}$} & \multirow{2}{*}{$\begin{array}{l}\text { Measured as } \\
\text { biovolume } \\
\text { or cell } \\
\text { density }\end{array}$} & \multicolumn{3}{|c|}{$\begin{array}{l}\text { Variable with no observed } \\
\text { threshold response to UII }\end{array}$} & \multicolumn{5}{|c|}{$\begin{array}{l}\text { Variables with an observed threshold } \\
\text { response to UII }\end{array}$} \\
\hline & & & $\mathbf{r}$ & $\mathbf{s}$ & $\mathbf{p}$ & $\begin{array}{l}\text { Threshold } \\
\text { UII }\end{array}$ & $\begin{array}{c}\begin{array}{c}\text { Pre- } \\
\text { threshold } \\
s\end{array} \\
\end{array}$ & $\begin{array}{c}\begin{array}{c}\text { Post- } \\
\text { threshold } \\
\text { s }\end{array} \\
\end{array}$ & $\mathbf{F}$ & $\mathbf{p}$ \\
\hline SP_AP_BP & RTH & Biovolume & .186 & .230 & .022 & -- & -- & -- & -- & -- \\
\hline ON_AH_BP & RTH & Biovolume & .374 & -.420 & $<.001$ & -- & -- & -- & -- & -- \\
\hline ON_HF_BP & $\mathrm{RTH}$ & Biovolume & .530 & .143 & .003 & -- & -- & -- & -- & -- \\
\hline ON_NH_BP & RTH & Biovolume & .413 & .457 & $<.001$ & -- & -- & -- & -- & -- \\
\hline PH_CN_BP & RTH & Biovolume & .231 & .317 & .001 & -- & -- & -- & -- & -- \\
\hline OT_VL_DP & RTH & Cell density & -- & -- & -- & 48 & .008 & .050 & 19.8 & $<.001$ \\
\hline ON_HF_DP & DTH & Biovolume & .426 & .183 & $<.001$ & -- & -- & -- & -- & -- \\
\hline ON_AL_DP & DTH & Cell density & .242 & -.316 & .015 & -- & -- & -- & -- & -- \\
\hline ON_NH_DP & DTH & Cell density & -- & -- & -- & 46 & -.084 & .728 & 5.480 & .029 \\
\hline TR_OM_DP & DTH & Cell density & .062 & .021 & .239 & -- & -- & -- & -- & -- \\
\hline TR_O_DP & DTH & Cell density & .159 & .094 & .054 & -- & -- & -- & -- & -- \\
\hline OT_VL_DP & DTH & Cell density & .219 & .059 & .021 & -- & -- & -- & -- & -- \\
\hline
\end{tabular}

Table 7. Values of land-use/land-cover, infrastructure, and socioeconomic variables for threshold values of physical and biological variables that showed significant threshold response to urban intensity index for subbasins in and near the Dallas-Fort Worth metropolitan area, Texas.

[See table 3 for definitions of variables; UII, urban intensity index; RTH, richest targeted habitat; DTH, depositional targeted habitat]

\begin{tabular}{|c|c|c|c|c|c|c|c|}
\hline \multirow[b]{2}{*}{$\begin{array}{c}\text { Physical or } \\
\text { biological } \\
\text { variable }\end{array}$} & \multirow{2}{*}{$\begin{array}{l}\text { Value of } \\
\text { physical or } \\
\text { biological } \\
\text { variable at } \\
\text { threshold UII }\end{array}$} & \multirow[b]{2}{*}{$\begin{array}{l}\text { Value of } \\
\text { Ull at } \\
\text { threshold }\end{array}$} & \multirow[b]{2}{*}{$\begin{array}{l}\text { Pre-/post-threshold } \\
\text { response to UII }\end{array}$} & \multicolumn{4}{|c|}{$\begin{array}{l}\text { Value of variables for threshold UII estimated } \\
\text { from regressing UII on variable }\end{array}$} \\
\hline & & & & $\begin{array}{l}\text { Percentage } \\
\text { developed }\end{array}$ & $\begin{array}{c}\text { Mean } \\
\text { percentage } \\
\text { impervious } \\
\text { surface }\end{array}$ & $\begin{array}{c}\text { Road density } \\
\text { (road length/ } \\
\text { watershed area) }\end{array}$ & $\begin{array}{c}\text { Density of } \\
\text { housing units } \\
\text { (housing units per } \\
\text { square kilometer) }\end{array}$ \\
\hline Mxl_25 & 480 & 32 & $\begin{array}{l}\text { Negative/positive } \\
\text { (fig. 8) }\end{array}$ & 17.0 & 6.54 & 19.2 & 13.0 \\
\hline $\begin{array}{l}\text { OT_VL_DP } \\
\text { (RTH algae) }\end{array}$ & 1.70 & 48 & $\begin{array}{l}\text { Positive/positive } \\
\quad \text { (fig. 12) }\end{array}$ & 32.1 & 13.6 & 35.7 & 28.6 \\
\hline $\begin{array}{l}\text { ON_NH_DP } \\
\text { (DTH algae) }\end{array}$ & 19.1 & 46 & $\begin{array}{c}\text { Negative/positive } \\
\text { (fig. 14) }\end{array}$ & 27.4 & 11.4 & 30.6 & 23.7 \\
\hline
\end{tabular}

\footnotetext{
${ }^{1}$ Regression equations:

Percentage developed (pNLCD1_2)

pNLCD1_2 $=-13.31+.946 *$ UII; correlation coefficient $=.95$

Mean percentage impervious surface (NLCD_IS)

NLCD_IS $=-7603+.442 *$ UII; correlation coefficient $=.94$

Road density (ROADDEN)

ROADDEN $=-13.74+1.03 *$ UII; correlation coefficient $=.96$

Density of housing units (HUDEN)

HUDEN $=-17.96+.969 *$ UII; correlation coefficient $=.93$
} 
stable agricultural intensity on such concentrations could be enough to mask potential effects of increasing urban intensity on concentrations. Another factor that might mask the effects of increasing urban intensity on nitrogen and phosphorus concentrations (and thus at least partially account for the lack of significant response of these variables to the UII) is the large variability in concentrations. Mid-1990s analyses of Trinity River Basin streams indicated that nutrient concentrations vary seasonally and are as much as 100 percent greater during spring than during winter (Land and others, 1998). Although the reasons cannot be explained with certainty, the finding of this study is that the UII is not correlated with concentrations of most chemicals.

\section{Physical Characteristics}

In the DFW area, several streamflow metrics of stream flashiness were significantly positively correlated with the UII. This correlation indicates that, in general as urbanization intensifies, flashiness increases. Each of the flashiness metrics had a linear but not a threshold response to the UII. The lack of a threshold response might be because of similar channel morphologies in urban and rural streams. Blackland Prairie streams generally are relatively narrow and deep in both landuse/land-cover settings. Blackland Prairie stream channels of this study are dominated by fine sediments, particularly clays that are slow to drain (Harmel and others, 2006). The high clay content of the Blackland Prairie soils contributes to relatively large depth-to-width ratios that are characteristic of the stream channels in this ecoregion by making the channels naturally resistant to expansion by flowing water.

Four flow-duration metrics were significantly negatively correlated with the UII. Decreasing flow duration with increasing UII is consistent with the increasing flashiness with increasing UII. This flow-duration result for the DFW area is consistent with findings for streams in the Birmingham, Ala., and Boston, Mass., urban areas (McMahon and others, 2003). The duration of a flow event has been recognized as one of five streamflow characteristics having an effect on stream ecosystems (Poff and Ward, 1989; Richter and others, 1996); and flow duration is a characteristic of streamflow that is useful in assessing the long-term effects of human-induced changes on stream hydrology (Poff and others, 1997).

Several possible explanations might account for the lack of a statistically significant response of any of the physical habitat measures to the UII in the DFW area. First, the lack of subbasins with mid-range UII scores (between about 50 and 75) could have influenced results of the rank correlation analyses. Second, many of the habitat variables are based on channel geometry, and the lack of a correlation between measures of channel form (such as the ratio of bankfull width to depth) and the UII indicates the lack of a strong relation between channel geometry and the UII. The lack of a significant response of variables based on channel geometry for the DFW area is consistent with the findings from NAWQA urban-gradient studies in the Boston, Mass., and Birmingham,
Ala., metropolitan areas (Short and others, 2005). Habitat variables associated with riparian vegetation might not be significantly correlated with the UII because one of the criteria for reach selection - similar native vegetation (as well as similar channel form and bed substrate) — would tend to exclude "different" reaches, that is, reaches with physical alterations of human origin. The "intensity" of the urban gradient used in this study might not have been of a level of urbanization to overcome underlying natural channel features such as bed slope and bed sediment (that is, silts and clays) characteristic of streams in the Blackland Prairie.

\section{Biological Characteristics}

Fish assemblages in urban streams generally are less diverse (May and others, 1997), have more exotic or nonnative species (DeVivo, 1996), and have more tolerant fish species (Scott and Helfman, 2001) than non-urban streams. The findings of this study - none of the fish metrics were significantly correlated with the UII-could have been caused by sampling bias because the fish assessments were done only once; obtaining seasonal data on fish might have changed the results. Fish are relatively large and mobile aquatic organisms, and a single assessment at each site might not be adequate to accurately determine fish species richness, numbers of individuals per species, or relative abundance, all of which are core information for the metrics of this study. In addition, an assessment of the presence or lack of hydrologic connectivity (Poff and Allan, 1995) along a gradient of urbanization, and the relation of hydrologic connectivity to fish assemblages, might provide some important information for future studies. Hydrologic connectivity refers to the continuity of water-mediated transport of matter, energy, or aquatic organisms within or between components of the hydrologic cycle (Pringle, 2003). In urban settings, in-channel structures such as dams, channelization for flood control, and bridges can disrupt the movement or migration of fishes resulting in a lack of connectivity for these aquatic organisms.

Predator richness and Margalef's richness from RTH benthic macroinvertebrate samples, both negatively correlated with the UII, and percentage of filterer-collector richness from QMH benthic macroinvertebrate samples, positively correlated with the UII, are three of the four benthic macroinvertebrate variables that are significantly correlated with the UII. A decrease in benthic macroinvertebrate predators in streams with larger UII scores could be in response to abiotic disturbance factors (Thomson and others, 2002) such as increased flooding of urban streams. A corresponding increase in the percentage of filterer-collectors with an increase in the UII might be a response to increased nutrient loadings to urban streams and a corresponding increase in algal productivity; however, increasing nutrient concentrations with increasing UII was not observed in this study. A decrease in the richness of Plecoptera, Ephemeroptera, and Trichoptera taxa in response to an increase in urbanization has been noted in other studies (Kennen and Ayers, 2002; Cuffney and others, 2005), 
and the loss of species of these taxa could account for decreasing Margalef's richness in relation to increasing UII for the DFW area.

Periphytic algae metrics determined from RTH and DTH samples indicated nitrogen-dependent responses to the UII despite the lack of a correlation between nitrogen concentrations in water and the UII. Algal community composition might reflect the influence of variable nutrient concentrations over time and not necessarily short-term antecedent nutrient conditions; water sampling for this report was done over a 5to 6-month period preceding the collection of algae samples. In addition, a minimum of two to a maximum of five water samples were collected at each site over the 5- to 6-month period prior to the collection of algae samples. Two to five water samples over this period might be too few to adequately characterize antecedent nutrient concentrations or availability. The results here lend support to the importance of assessing the algal communities in the Blackland Prairie streams to understand stream-nutrient conditions or eutrophic status in addition to, or as a surrogate for, the collection of water samples for the analysis of nutrients.

Several RTH and DTH periphytic algae metrics indicated an increase in periphytic algae that respond to low dissolved oxygen concentrations with an increase in the UII. Urban streams might have relatively high water temperatures, relatively less over-stream canopy, and relatively low base flows that can contribute to the presence of oxygen-tolerant aquatic biota. The fish and benthic macroinvertebrate communities did not indicate an increase in tolerant taxa with an increase in the UII in the DFW area. However, neither low-oxygentolerant fish nor benthic invertebrate taxa were addressed for this report.

\section{Summary}

In 2001, the U.S. Geological Survey National Water Quality Assessment (NAWQA) Program began a series of studies in the contiguous United States to examine the effects of urbanization on the chemical, physical, and biological characteristics of streams. Six NAWQA Study Units were selected, one of which was the Trinity River Basin Study Unit in Texas. Small streams in the Texas Blackland Prairie level III ecoregion in and near the Dallas-Fort Worth metropolitan area were the focus of the study. The principal objectives of the study were to (1) define a gradient of urbanization for small Blackland Prairie streams in the Trinity River Basin on the basis of a range of urban intensity indexes (UIIs) calculated using land-use/land-cover, infrastructure, and socioeconomic characteristics; (2) assess the relation between this gradient of urbanization and the chemical, physical, and biological characteristics of these streams; and (3) evaluate the type of relation (that is, linear or nonlinear, and whether there was a threshold response) of the chemical, physical, and biological characteristics of these streams to the gradient of urbanization.
This report describes the effects of urbanization on the chemical, physical, and biological characteristics of small Blackland Prairie streams on the basis of data collected in 2003-04. Twenty-eight subbasins in the Texas Blackland Prairie level III ecoregion with drainage areas ranging from about 25 to 290 square kilometers were selected for this study. Land-use/land-cover, infrastructure, and socioeconomic characteristics of each subbasin were determined and used to calculate a UII for each subbasin. Land-use/land-cover features were determined for a stream segment at the terminus or node of each subbasin; segment length was based on subbasin drainage area. A reach at least 150 meters long within the selected segment and upstream from the terminus of each subbasin was selected for data collection. Reaches were selected to minimize between-reach differences in riparian vegetation, channel morphology, and substrate of the streambed. Chemical characteristics evaluated in each reach included sulfate, chloride, nutrients, pesticides, dissolved and particulate carbon, and suspended sediment; the physical characteristics included stream stage, water temperature, and stream habitat; biological characteristics included fish, benthic macroinvertebrate, and algae communities.

The principal objective of data analysis for this report was to determine whether the chemical, physical, or biological variables or metrics measured related to the gradient of urbanization as defined by the UIIs standardized to a scale of 0 to 100 and sorted from smallest to largest. In addition, for those variables or metrics that indicated a statistically significant relation with the gradient of urbanization, a threshold analysis was done to determine whether the response was linear or nonlinear. Spearman's rho correlation was used to evaluate the relations between the various chemical, physical, and biological variables and the UII. Chemical, physical, and biological variables correlated with the UII were retained for threshold analysis to indicate any pattern of response to the UII. Locally weighted scatterplot smoothing (LOWESS) was used to indicate the presence of a threshold response. After threshold analysis yielded the chemical, physical, and biological variables that showed significant threshold responses to the UII, linear regression between the UII and selected land-use/ land-cover, infrastructure, and scioeconomic variables (those most strongly correlated with the UII based on Spearman's rho tests) was used to estimate the value of each land-use/landcover, infrastructure, and scioeconomic variable for the corresponding UII score at the observed threshold. Each selected land-use/land-cover, infrastructure, and scioeconomic variable was regressed on the UII, yielding a regression equation for each. Then the value of each of land-use/land-cover, infrastructure, and scioeconomic variable for the threshold value of each chemical, physical, and biological variable that showed a significant threshold response to the UII was estimated from the respective regression equation.

Ninety-four water-chemistry variables and one measure of potential toxicity from a bioassay were compared to the UII using Spearman's rho correlation. Of these comparisons, the concentrations of two pesticides (diazinon and simazine) 
and one measure of potential toxicity (P450RGS assay) from compounds sequestered in semipermeable membrane devices were significantly positively correlated with the UII. No threshold responses to the UII for diazinon and simazine concentrations were observed over the entire range of UII scores. The linear correlation for diazinon with the UII was significant, but the linear correlation for simazine with the UII was not. The P450RGS assay indicated a threshold response to the UII, but testing indicated the response was not significant. No statistically significant relations between the UII and concentrations of suspended sediment, total nitrogen, total phosphorous, or any of the major ions were indicated.

Eleven of 59 physical variables from streamflow were significantly correlated with the UII. Temperature was not significantly correlated with the UII, and none of the physical habitat measurements were significantly correlated with the UII. Seven physical variables categorized as streamflow flashiness metrics were significantly positively correlated with the UII. Two of the flashiness metrics showed a linear but not a threshold response to the UII. Four flow-duration metrics were significantly negatively correlated with the UII. Two of the four showed a linear response to the UII, one showed a threshold response, and one showed neither.

None of the fish metrics, which include a regional index of biotic integrity (IBI) for the Blackland Prairie, individual IBI metrics, number of fish collected, or fish species richness, were significantly correlated with the UII in the Blackland Prairie streams.

Two qualitative multi-habitat (QMH) benthic macroinvertebrate metrics, predator richness and percentage filterercollector richness, were significantly correlated with the UII; predator richness was negatively correlated with the UII, and percentage filterer-collector richness was positively correlated with the UII. No threshold response to the UII was observed for either metric, but both showed a significant linear response to the UII.

Three richest targeted habitat (RTH) benthic macroinvertebrate metrics, Margalef's richness, predator richness, and omnivore richness were significantly negatively correlated with the UII. Margalef's richness was the only RTH metric that indicated a threshold response to the UII.

The majority of unique taxa collected in the periphytic algae samples were diatoms. Six RTH periphytic algae metrics were correlated with the UII. Of the six RTH periphytic algae metrics, five showed no notable threshold response to the UII; but all five showed significant linear responses to the UII. Only the metric OT_VL_DP, which indicates the presence of algae that are tolerant of low dissolved oxygen conditions, showed a threshold response to the UII. Six depositional target habitat (DTH) periphytic algae metrics were correlated with the UII. Of the six, five showed no threshold response to the UII; three of the five showed significant linear responses to the UII, one showed a borderline significant response ( $\mathrm{p}$-value equals .054), and one showed no significant response. Only the nitrogen heterotrophic metric ON_NH_DP, which indicates the presence of algal taxa tolerant to elevated concentrations of organically bound nitrogen, showed a threshold response.

The land-use/land-cover, infrastructure, and scioeconomic variables that were most strongly correlated with the UII are percentage developed, mean percentage impervious surface, road density, and density of housing units. The magnitudes of the estimated threshold values of all four land-use/ land-cover, infrastructure, and scioeconomic variables, estimated by regression of each variable on the UII, for each of the four physical and biological variables ranked the same as the threshold values of the UII for the physical and biological variables.

Regarding responses of chemical characteristics (variables) to the gradient of urban intensity, the lack of a threshold response to the UII for diazinon and simazine might indicate the widespread use of these pesticides across a range of rural and urban settings in the DFW area. The finding that potential toxicity as indicated by P450RGS assay is significantly positively correlated with the UII indicates that potential toxicity from compounds such as polycyclic aromatic hydrocarbons, polychlorinated biphenyls, and polychlorinated dibenzo- $p$ dioxins/polychlorinated dibenzofurans increased with urbanization in the DFW subbasins.

Regarding responses of physical characteristics to the gradient of urban intensity, the significant positive correlation with the UII of metrics of stream flashiness indicates that, in general as urbanization intensifies, flashiness increases. The lack of a threshold response to the UII among flashiness metrics might be because of similar channel morphologies in urban and rural streams. Results showing flow-duration metrics significantly negatively correlated with the UII are consistent with the increasing flashiness with increasing UII.

Regarding responses of biological characteristics to the gradient of urban intensity, the fact that none of the fish metrics were significantly correlated with the UII could have been caused by sampling bias because the fish assessments were done only once; obtaining seasonal data on fish might have changed the results. Predator richness and Margalef's richness from RTH samples are significantly negatively correlated with the UII, and percentage of filterer-collector richness from QMH samples are significantly positively correlated with the UII. A decrease in benthic macroinvertebrate predators in streams with larger UII scores could be in response to abiotic disturbance factors such as increased flooding of urban streams. A corresponding increase in the percentage of filterer-collectors with an increase in the UII might be a response to increased nutrient loadings to urban streams and a corresponding increase in algal productivity, although increasing nutrient concentrations with increasing UII was not observed in this study. A decrease in the richness of Plecoptera, Ephemeroptera, and Trichoptera taxa in response to an increase in urbanization has been noted in two other studies, and the loss of species of these taxa could account for decreasing Margalef's richness in relation to increasing UII. Periphytic algae metrics determined from RTH and DTH samples indicated nitrogen-dependent responses to the UII despite 
the lack of a correlation between nitrogen concentrations in water and the UII. Algal community composition might reflect the influence of variable nutrient concentrations over time and not necessarily short-term antecedent nutrient conditions; water sampling for this report was done over a 5- to 6-month period preceding the collection of algae samples. Several RTH and DTH periphytic algae metrics indicated an increase in periphytic algae that respond to low dissolved oxygen concentrations with an increase in the UII.

\section{References Cited}

Ahel, M.E., Molnar, E., Ibric, S., and Giger, W., 2000, Estrogenic metabolites of alkylphenol polyethoxylates in secondary sewage effluents and rivers: Water Science and Technology, v. 42, p. 15-22.

Anderson, J.W., Rossi, S.S., Tukey, R.H., Vu, Tien, and Quattrochi, L.C., 1995, A biomarker, P450 RGS, for assessing the induction potential of environmental samples: Environmental Toxicology and Chemistry, v. 14, p. 1,159-1,169.

Arar, E.J., and Collins, G.B., 1997, U.S. Environmental Protection Agency method 445.0, in vitro determination of chlorophyll $a$ and pheophytin $a$ in marine and freshwater algae by fluorescence, revision 1.2: Cincinnati, Ohio, U.S. Environmental Protection Agency, National Exposure Research Laboratory, Office of Research and Development, $22 \mathrm{p}$.

Arnold, C.L., and Gibbons, C.J., 1996, Impervious surface coverage-The emergence of a key environmental indicator: American Planners Association Journal, v. 62, p. 243-258.

Booth, D.B., and Jackson, C.R., 1997, Urbanization of aquatic systems-Degradation thresholds, stormwater detection, and the limits of mitigation: Journal of the American Water Resources Association, v. 33, p. 1,077-1,090.

Brenton, R.W., and Arnett, T.L., 1993, Methods of analysis by the U.S. Geological Survey National Water Quality Laboratory-Determination of dissolved organic carbon by UVpromoted persulfate oxidation and infrared spectrometry: U.S. Geological Survey Open-File Report 92-480, 12 p.

Britton, L.J., and Greeson, P.W., eds, 1987, Methods for collection and analyses of aquatic biological and microbiological samples: U.S. Geological Survey Techniques of WaterResources Investigations, book 5, chap. A4, p. 139-140.

Brown, D.G., Johnson, K.M., Loveland, T.R., and Theobald, D.M., 2005, Rural land-use trends in the conterminous United States, 1950-2000: Ecological Applications, v. 15, p. $1,851-1,863$.

Bryant, W.L., Goodbred, S.L., Leiker, T.L., Inouye, Laura, and Johnson, B.T., 2007, Use of chemical analysis and assays of semipermeable membrane devices extracts to assess the response of bioavailable organic pollutants in streams to urbanization in six metropolitan areas of the United States: U.S. Geological Survey Scientific Investigations Report 2007-5113, 58 p.

Charles, D.F., Candia, K., and Davis, R.S., eds., 2002, Protocols for the analysis of the algae collected as part of the U.S. Geological Survey National Water Quality Assessment Program: Philadelphia, Academy of Natural Sciences Report 02-06, 124 p.

Couch, Carol, and Hamilton, Pixie, 2002, Effects of urbanization on stream ecosystems: U.S. Geological Survey Fact Sheet 042-02, $4 \mathrm{p}$.

Cuffney, T.F., Zappia, Humbert, Giddings, E.M.P., and Coles, J.F., 2005, Effects of urbanization on benthic macroinvertebrate assemblages in contrasting environmental settingsBoston, Massachusetts; Birmingham, Alabama; and Salt Lake City, Utah, in Brown, L.R., Gray, R.H., Hudges, R.M., and Meador, M.R., eds., Effects of urbanization on stream ecosystems: Bethesda, Md., American Fisheries Society Symposium 47, p. 361-407.

DeVivo, J.C., 1996, Fish assemblages as indicators of water quality within the Apalachicola-Chattahoochee-Flint River Basin: Athens, Ga., University of Georgia, Masters Thesis.

Falcone, James, Stewart, J.S., Sobieszczyk, Steven, Dupree, J.A., McMahon, Gerard, and Buell, G.R., 2007, A comparison of natural and urban characteristics and the development of urban intensity indices across six geographic settings: U.S. Geological Survey Scientific Investigations Report 2007-5123, 133 p.

Fishman, M.J., 1993, Methods of analysis by the U.S. Geological Survey National Water Quality Laboratory-Determination of inorganic and organic constituents in water and fluvial sediments: U.S. Geological Survey Open-File Report 93-125, $217 \mathrm{p}$.

Fishman, M.J., and Friedman, L.C., 1989, Methods for determination of inorganic substances in water and fluvial sediments: U.S. Geological Survey Techniques of WaterResources Investigations, book 5, chap. A1, 545 p.

Fitzpatrick, F.A., Waite, I.R., D'Arconte, P.J., Meadore, M.R., Maupin, M.A., and Gurtz, M.E., 1998, Revised methods for characterizing stream habitat in the National Water Quality Assessment Program: U.S. Geological Survey WaterResources Investigations Report 98-4052, 67 p.

Giddings, E.M.P., Bell, A.H., Beaulieu, K.M., Cuffney, T.F., Coles, J.F., Brown, L.R., Fitzpatrick, F.A., Falcone, James, Sprague, L.A., Bryant, W.L., Peppler, M.C., Stephens, Cory, and McMahon, Gerard, 2009, Selected physical, chemical, and biological data used to study urbanizing streams in nine metropolitan areas of the United States, 1999-2004: U.S. Geological Survey Data Series 423, 11 p. plus data tables.

Gregory, K.J., Davis, R.J., and Downs, P.W., 1992, Identification of river channel change due to urbanization: Applied Geography, v. 12, p. 299-318. 
Griffith, G.E., Bryce, S.A., Omernick, J.M., Comstock, J.A., Rogers, A.C., Harrison, B., Hatch, S.L., and Bezanson, D., 2004, Ecoregions of Texas [color poster with map, descriptive text, and photographs]: Reston, Va., U.S. Geological Survey, scale 1:2,500,000.

Harmel, R.D., Richardson, C.W., King, K.W., and Allen, P.M., 2006, Runoff and soil loss relationships for the Texas Blackland Prairies ecoregion: Journal of Hydrology, v. 331, p. $471-483$.

Horner, R.R., Booth, B.D., Azous, A., and May, C.W., 1997, Watershed determinants of ecosystem functioning, in Roessner, C., ed., Effects of watershed development and management on aquatic ecosystems: New York, American Society of Civil Engineers, p. 251-274.

Huckins, J.N., Manuweera, G.K., Petty, J.D., Mackay, Donald, and Lebo, J.A., 1993, Lipid-containing semipermeable membrane devices for monitoring organic contaminants in water: Environmental Science and Technology, v. 27, p. 2,849-2,496.

Huckins, J.N., Tubergen, M.W., and Manuweera, G.K., 1990, Semipermeable membrane devices containing model lipidA new approach to monitoring the availability of lipophilic contaminants and estimating their bioconcentration potential: Chemosphere, v. 20, p. 533-552.

Jacobson, R.B., Femmer, S.R., and McKenny, R.A., 2001, Land-use changes and the physical habitat of streams-A review with emphasis on studies within the U.S. Geological Survey Federal-State cooperative program: U.S. Geological Survey Circular 1175, 63 p.

Johnson, B.T., 1998, Microtox toxicity test system-New developments and applications, in Wells, P.G., Lee, Kenneth, and Blaise, Christian, eds., Microscale testing in aquatic toxicology-Advances, techniques and practice: Boca Raton, Fla., CRC Lewis Publishers, p. 201-218.

Johnson, B.T., Petty, J.D., Huckins, J.N., Lee, Ken, and Gauthier, Joanne, 2004, Hazard assessment of a simulated oil spill on intertidal areas of the St. Lawrence River with SPMD-TOX: Environmental Toxicology, v. 19, p. 329-335.

Johnson, K.M., 1998, Renewed population growth in rural America: Research in Rural Sociology and Development, v. 7, p. 23-45.

Jones, R.C., and Clark, C.C., 1987, Impact of watershed urbanization on stream insect communities: Water Resources Bulletin, v. 23, p. 1,047-1,055.

Karr, J.R., and Chu, E.W., 1999, Restoring life in running waters-Better biological monitoring: Covelo, Calif., Island Press, 667 p.

Kennen, J.G., and Ayers, M.A., 2002, Relation of environmental characteristics to the composition of aquatic assemblages along a gradient of urban land use in New Jersey: U.S.
Geological Survey Water-Resources Investigations Report 02-4069, $77 \mathrm{p}$.

Klein, R.D., 1979, Urbanization and stream quality impairment: Water Resources Bulletin, v. 15, p. 948-963.

Land, L.F., Moring, J.B., Van Metre, P.C., Reutter, D.C., Mahler, B.J., Shipp, A.A., and Ulery, R.L., 1998, Water quality in the Trinity River Basin, Texas, 1992-95: U.S. Geological Survey Circular Report 1171, 39 p.

LeBlanc, R.T., Brown, R.D., and FitzGibbon, J.E., 1997, Modeling the effects of land use change on the water temperature in unregulated streams: Journal of Environmental Management, v. 49, p. 445-469.

Linam, G.W., Kleinsasser, L.J., and Mayes, K.B., 2002, Regionalization of the index of biotic integrity for Texas streams: Texas Parks and Wildlife Department, Resource Protection Division, River Studies Report No. 17, 140 p.

Martin, D.J., Wasserman, L.J., and Dale, V.H., 1986, Influence of riparian vegetation on posteruption survival of coho salmon fingerlings on the west-side streams of Mount St. Helens, Washington: North American Journal of Fisheries Management, v. 6, p. 1-8.

May, C.W., Horner, R.R., Karr, J.R., Mar, B.W., and Welch, E.B., 1997, Effects of urbanization on small streams in the Puget Sound Lowland ecoregion: Watershed Protection Techniques, v. 2, p. 483-494.

McDonnell, M.J., and Picket, S.T.A., 1990, Ecosystem structure and function along urban-rural gradients-An unexploited opportunity for ecology: Ecology, v. 71, p. 1,231-1,237.

McMahon, Gerard, Bales, J.D., Coles, J.F., Giddings, E.M.P., and Zappia, Humbert, 2003, Use of stage data to characterize hydrologic conditions in an urbanizing environment: Journal of the American Water Resources Association, v. 39 , p. 1,529-1,546.

McMahon, Gerard, and Cuffney, T.F., 2000, Quantifying urban intensity in drainage basins for assessing stream ecological conditions: Journal of the American Water Resources Association, v. 36, p. 1,247-1,262.

Meador, M.R., Coles, J.F., and Zappia, Humbert, 2005, Fish assemblage responses to urban intensity gradients in contrasting metropolitan areas-Birmingham, Alabama and Boston, Massachusetts, in Brown, L.R., Gray, R.H., Hudges, R.M., and Meador, M.R., eds., Effects of urbanization on stream ecosystems: Bethesda, Md., American Fisheries Society Symposium 47, p. 409-423.

Moulton, S.R., II, Carter, J.L., Grotheer, S.A., Cuffney, T.F., and Short, T.M., 2000, Methods for analysis by the U.S. Geological Survey National Water Quality LaboratoryProcessing, taxonomy, and quality control of invertebrate samples: U.S. Geological Survey Open-File Report 02-212, $49 \mathrm{p}$. 
Moulton, S.R., Kennen, J.G., Goldstein, R.M., and Hambrook, J.A., 2002, Revised protocols for sampling algal, invertebrate, and fish communities as part of the National Water Quality Assessment Program: U.S. Geological Survey Open-File Report 02-150, 87 p.

Murk, A.J., Legler, J., Penison, M.S., Giesy, J.P., Vande Gutche, C., and Brouwer, A., 1996, Chemical activated luciferase gene expression (calux) - A novel in vitro bioassay for AH receptor active compounds in sediment and pore water: Fundamental and Applied Toxicology, v. 33, p. 149-160.

Nather Khan, I.S.A., 1991, Effect of urban and industrial wastes on species diversity of the diatom community in a tropical river, Malaysia: Hydrobiologia, v. 224, p. 175-184.

National Climatic Data Center, 2008, Local climatological data publication-Texas; Dallas-Fort Worth International Airport [DFW] 1953-04 - 2008-02 (03927): U.S. Department of Commerce; National Oceanic and Atmospheric Administration; National Environmental Satellite, Data, and Information Service, accessed April 21, 2008, at http://www7.ncdc.noaa.gov/IPS/LCDPubs?action=getstate

Omernick, J.N., 1987, Ecoregions of the conterminous United States: Annals of the Association of American Geographers, v. 77, p. 118-125.

Park, H.M., 2004, Understanding the statistical power of a test: University Information Technical Services Center for Statistical and Mathematical Computing, University of Indiana, accessed January 30, 2007, at http://www.indiana. edu/ statmath/stat/all/power/power.pdf

Paul, M.J., and Meyer, J.L., 2001, Streams in the urban landscape: Annual Review of Ecology and Sytematics, v. 32, p. 333-365.

Petts, G.E., 1989, Perspectives for ecological management of regulated rivers, in Gore, J.A., and Petts, G.E., eds., Alternatives in regulated river management: Boca Raton, Fla., CRC Press, p. 3-24.

Poff, N.L., and Allan, J.D., 1995, Functional organization of stream fish assemblages in relation to hydrological variability: Ecology, v. 76, p. 606-627.

Poff, N.L., Allan, J.D., Bain, M.B., Karr, J.R., Prestegaard, K.L., Richter, B.D., Sparks, R.E., and Stromberg, J.C., 1997, The natural flow regime-A paradigm for river conservation and restoration: Bioscience, v. 47, p. 769-784.

Poff, N.L., and Ward, J.V., 1989, Implications of streamflow variability and predictability for lotic community structure-A regional analysis of streamflow patterns: Canadian Journal of Fisheries and Aquatic Sciences, v. 46, p. 1,805-1,818.

Postel, S.L., 2000, Entering an era of water scarcityThe challenge ahead: Ecological Applications, v. 10, p. 941-948.
Potapova, Marina, Coles, J.F., Giddings, E.M.P., and Zappia, Humbert, 2005, A comparison of the influences of urbanization in contrasting environmental settings on stream benthic algal assemblages, in Brown, L.R., Gray, R.H., Hudges, R.M., and Meador, M.R., eds., Effects of urbanization on stream ecosystems: Bethesda, Md., American Fisheries Society Symposium 47, p. 333-359.

Pringle, C., 2003, What is hydrologic connectivity and why is it important: Hydrologic Processes (Invited Commentary), v. 17 , p. 2,685-2,689.

Richter, B.D., Baumgartner, J.V., Powell, J., and Braun, D.P., 1996, A method for assessing hydrologic alteration within ecosystems: Conservation Biology, v. 10, p. 1,163-1,174.

Roy, A.H., Rosemona, A.D., Paul, M.J., Leigh, D.S., and Wallace, J., 2003, Stream macroinvertebrate response to catchment urbanization: Freshwater Biology, v. 48, p. 329-346.

Sala, O.E., Chapin, F.S., III, Armesto, J.J., Berlow, E., Bloomfield, J., Dirzo, R., Huber-Sanwald, E., Huenneke, L.F., Jackson, R.B., Kinzig, A., Leemands, R., Lodge, D.M., Mooney, H.A., Oesterheld, M., Poff, N.L., Sykes, M.T., Walker, B.H., Walker, M., and Wall, D.H., 2000, Global biodiversity scenarios for the year 2100: Science, v. 287, p. 1,770-1,774.

Sauer, V.B., 2002, Standards for the analysis and processing of surface-water data and information using electronic methods: U.S. Geological Survey Water-Resources Investigations Report 01-4044, 92 p.

Scott, M.C., and Helfman, G.S., 2001, Native invasions, homogenization, and the mismeasure of integrity of fish assemblages: American Fisheries Society, v. 26, p. 6-15.

Shinya, M., Tsuchinaga, T., Kitano, M., Yamada, Y., and Ishikawa, M., 2000, Characterization of heavy metals and polycyclic aromatic hydrocarbons in urban highway runoff: Water Science and Technology, v. 42, p. 201-208.

Short, T.M., Giddings E.M.P., Zappia, Humbert, and Coles, J.F., 2005, Urbanization effects on stream habitat characteristics in Boston, Massachusetts; Birmingham, Alabama; and Salt Lake City, Utah, in Brown, L.R., Gray, R.H., Hudges, R.M., and Meador, M.R., eds., Effects of urbanization on stream ecosystems: Bethesda, Md., American Fisheries Society Symposium 47, p. 317-332.

Sinokrot, B.A., and Stefan, H.G., 1993, Stream temperature dynamics-Measurements and modeling: Water Resources Research, v. 29, p. 2,299-2,312.

Soil Conservation Service, 1981, Land resource regions and major land resource areas of the United States: U.S. Department of Agriculture Soil Conservation Service Handbook 296, p. 62-63, accessed April 20, 2008, a http://soilphysics. okstate.edu/S257/south/mlra/86.htm 
Sprague, L.A., Harned, D.A., Hall, D.W., Nowell, L.H., Bauch, N.J., and Richards, K.D., 2007, Response of stream chemistry during base flow to gradients of urbanization in selected locations across the conterminous United States, 2002-04: U.S. Geological Survey Scientific Investigations Report 2007-5083, 132 p.

Sprague, L.A., Zuellig, R.E., and Dupress, J.A., 2006, Effects of urbanization on stream ecosystems in the South Platte River Basin, Colorado and Wyoming: U.S. Geological Survey Scientific Investigations Report 2006-5101A, $141 \mathrm{p}$.

StatSoft, Inc., 2006, STATISTICA for Windows and Windows 95/98/NT: Tulsa, Okla., Statsoft, Inc.

Taylor, S.L., Roberts, S.C., Walsh, C.J., and Hatt, B.E., 2004, Catchment urbanization and increased benthic algal blooms in streams-Linking mechanisms to management: Freshwater Biology, v. 49, p. 835-851.

Texas Parks and Wildlife Department, 2007, Blackland Prairie ecological region: accessed December 11, 2007, at http://www.tpwd.state.tx.us/landwater/land/habitats/ cross_timbers/ecoregions/blackland.phtml

Thomson, R.T., Lake, P.S., and Downes, B.J., 2002, The effect of hydrological disturbance on the impact of a benthic invertebrate predator: Ecology, v. 83, p. 628-642.

Thuren, A., 1986, Determination of phthalates in aquatic environments: Bulletin of Environmental Contamination and Toxicology, v. 46, p. 159-166.

Trimble, S.W., 1997, Contribution of stream channel erosion to sediment yield from an urbanizing watershed: Science, v. 278 , p. $1,442-1,444$.

Ulery, R.L., Van Metre, P.C., and Crossfield, A.S., 1993, Trinity River Basin, Texas: American Water Resources Association, Water Resources Bulletin, v. 29, p. 685-711.

United Nations, 2004, World urbanization prospects-The 2003 revision: United Nations, Department of Economic and Social Affairs, Population Division, Publication E.04. XIII.6, ISBN 92-1-141396-0, 323 p.

U.S. Census Bureau, 2001, United States census 2000-Ranking tables for metropolitan areas-Population in 2000 and population change from 1990 to 2000 (PAC-T-3): accessed December 11, 2007, at http://www.census.gov/population/ www/cen2000/phc-t3.html

U.S. Environmental Protection Agency, 1997, Urbanization and streams-Studies of hydrologic impacts: Washington, D.C., U.S. Environmental Protection Agency Report EPA841-R-97-009, 18 p.
U.S. Geological Survey, variously dated, National field manual for the collection of water-quality data: U.S. Geological Survey Techniques of Water-Resources Investigations, book 9, chaps. A1-A9, available online at http://pubs.water.usgs. gov/twri9A

U.S. Geological Survey, 2008, National elevation dataset (NED): U.S. Geological Survey, available online at http://ned.usgs.gov/

Vannote, R.L., Minshall, G.W., Cummins, K.W., Sedel, J.R., and Cushing, C.E., 1980, The river continuum concept: Canadian Journal of Fisheries and Aquatic Sciences, v. 37, p. 130-137.

Volstad, J.H., Roth, N.E., Mercurio, G., Southerland, M.T., and Strebel, D.E., 2003, Using environmental stressor information to predict the ecological status of Maryland nontidal streams as measured by biological indicators: Environmental Monitoring and Assessment, v. 84, p. 219-242.

Walsh, C.J., Sharpe, A.K., Breen, P.F., and Sonneman, J.A., 2001, Effects of urbanization on streams of the Melbourne region, Victoria, Australia-I. Benthic macroinvertebrate communities: Freshwater Biology, v. 46, p. 535-551.

Wang, L., Lyons, J., Kanehl, P., Bannerman, R., and Emmons, E., 2000, Watershed urbanization and changes in fish communities in southeastern Wisconsin streams: Journal of the American Water Resources Association, v. 35, p. $1,173-1,189$.

Weaver, L.A., and Garman, G.C., 1994, Urbanization of a watershed and historical changes in a stream fish assemblage: Transactions of the American Fisheries Society, v. 123 , p. $162-172$.

Whitlow, J.R., and Gregory, K.J., 1989, Changes in urban stream channels in Zimbabwe: Regulated Rivers Resource Management, v. 4, p. 27-42.

Yoder, C.O., Miltner, R.J., and White, D., 1999, Assessing the status of aquatic life designated uses in urban and suburban watersheds, in Everson, A., Minamyer, S., Dye, J., Heimbrock, P., and Wilson, S., eds., National conference on retrofit opportunities for water resource protections in urban environments: Washington, D.C., U.S. Environmental Protection Agency Report EPA/625/R-99/002, p. 16-28.

Zaugg, D.S., Sandstrom, M.W., Smith, S.G., and Fehlberg, K.M., 1995, Methods of analysis by the U.S. Geological Survey National Water Quality Laboratory-Determination of pesticides in water by $\mathrm{C}-18$ solid-phase extraction and capillary-column gas chromatography/mass spectrometry with selected-ion monitoring: U.S. Geological Survey Open-File Report 95-181, 49 p. 
Publishing support provided by Lafayette Publishing Service Center

Information regarding water resources in Texas is available at http://tx.usgs.gov/ 


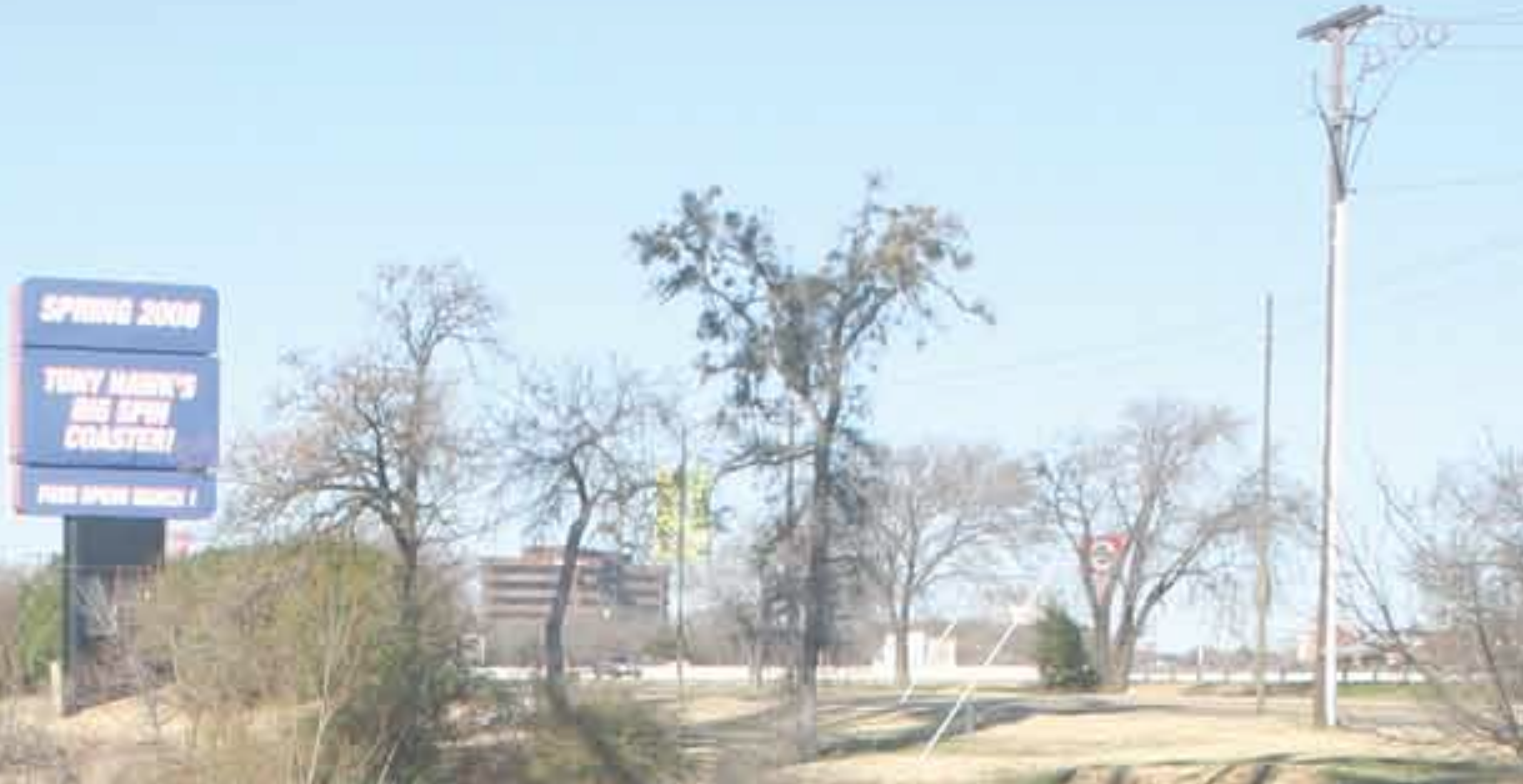

\section{8}

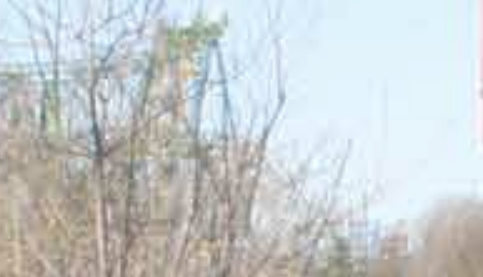

1.

$+2 \log ^{2}$

(1)

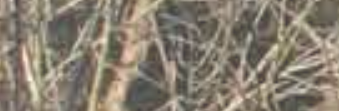

- 201512

15its

W.

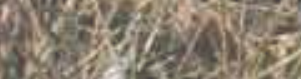

(1)

3)

1.cits

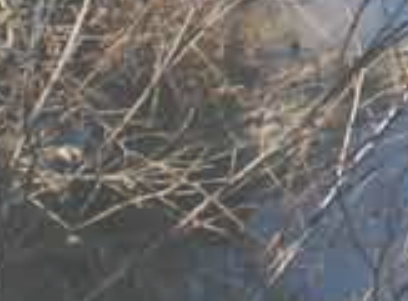

(2)

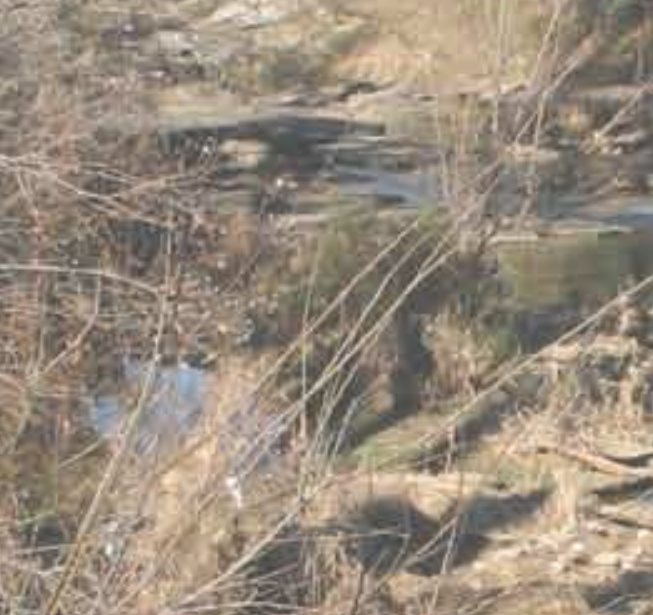

s.m.

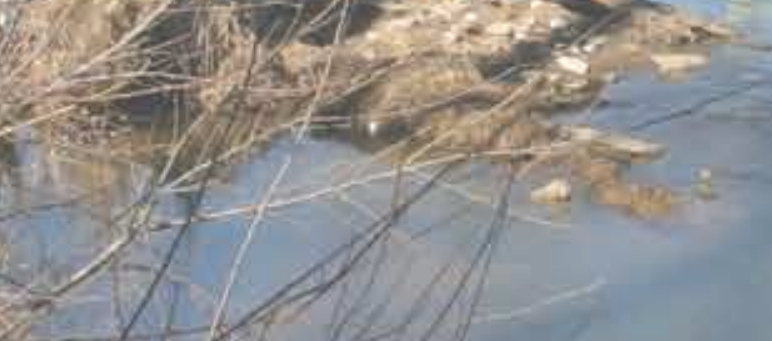
a

ISBN 978-1-4113-2427-5

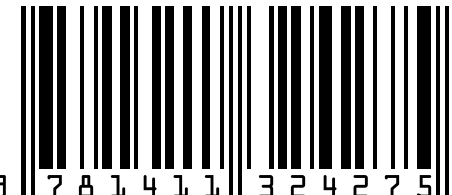

